\title{
LABOUR MARKET REGULATION, INDUSTRIAL RELATIONS, AND TECHNOLOGICAL REGIMES: A TALE OF COMPARATIVE ADVANTAGE
}

\author{
Andrea BASSANINI* and Ekkehard ERNST*
}

The views expressed here cannot be attributed to the OECD Secretariat or its Member Countries. We thank especially Eve Caroli, Sebastien Jean and Giuseppe Nicoletti for many comments and discussions on a previous draft. Helpful comments were also provided by Giovanni Dosi, Ignazio Visco, John Martin, Jorgen Elmeskov, Stefano Scarpetta, Paul Swaim, and Dominique Guellec to whom we are also in debt for providing us with the data on patents. We are also grateful to Walter Park for the data on IPR protection. Olivier Boylaud was very helpful in data management and Martine Levasseur provided excellent research assistance. Usual disclaimers apply.

* OECD, DEELSA. E-mail: andrea.bassanini@ oecd.org.

• OECD, Economics Department, and CEPREMAP. E-mail: ekkehard.ernst@ oecd.org. 


\title{
REglementation DU MARCHE DU TRAVAIL, RELATIONS DU TravaIL, ET Regimes TeChNOLOgIQUeS: Un CONTE D’Avantages COMParatifs
}

\begin{abstract}
Résumé: Dans ce papier nous présentons de l'évidence comparative concernant l'impact de la réglementation des marchés du travail et des produits sur l'innovation dans les pays de l'OCDE. Même si une telle réglementation a en général pour but des objectives autres que l'innovation, elle peut avoir des conséquences importantes pour la rentabilité des stratégies innovatrices des entreprises. Nos régressions avancent de l'évidence transversale qu'une augmentation de la concurrence sur le marché des produits - tout en garantissant les droits de propriété intellectuelle semble avoir un impact positif sur la performance innovatrice d'un pays. En revanche, la relation entre l'innovation et la flexibilité du marché du travail ne semble pas être sans ambiguïté. Le signe et l'importance de cette dernière dépend de manière cruciale du système des relations du travail et des caractéristiques de chaque industrie. En effet, plus les marchés internes du travail sont importants, moins la réglementation du marché du travail impose des coûts d'ajustement. Par ailleurs, dans les industries avec une base de connaissance cumulative, la protection de l'emploi et la coordination du système des relations du travail permettent aux entreprises d'exploiter pleinement le potentiel du marché interne du travail en alignant les objectifs des employés et des employeurs et en encourageant la formation financée par les entreprises ainsi que l'accumulation des compétences spécifiques à la firme.
\end{abstract}

\section{LABOUR MARKET REGULATION, INDUSTRIAL RELATIONS, AND TECHNOLOGICAL REGIMES: A TALE OF COMPARATIVE ADVANTAGE}

\begin{abstract}
In this paper we present comparative evidence from OECD countries concerning the impact of labour market institutions and regulations on technological specialisation. The interplay between the degree of labour market flexibility, the systems of industrial relations and the knowledge base of different industries determines the viability of different human resource strategies thereby shaping the patterns of comparative advantage. Our empirical results show that countries with coordinated industrial-relations systems and strict employment protection tend to specialise in industries with a cumulative knowledge base. We argue that two mechanisms explain these patterns. The larger the scope for resorting to internal labour markets, the lower the adjustment costs imposed by labour market regulation. Furthermore, employment protection and coordinated industrial-relations regimes, by aligning workers' and firms' objectives, encourage firm-sponsored training as well as the accumulation of firm-specific competencies, allowing firms to fully exploit the potential of the internal labour market.
\end{abstract}

Mots-clefs : Réglementation, Rapport salarial, Avantages comparatives technologiques, Régimes technologiques, Accumulation des compétences

Keywords: Regulation, Industrial relations, Technological comparative advantage, Technological regimes, Competence accumulation.

JEL Classification: O31, O33, J50 


\section{Introduction}

In recent years, there has been quite a lot of attention to the role of institutions in shaping economic performance and specialisation patterns across countries. Although labour market policies usually aim at objectives other than innovation, some authors have argued that they may have important consequences for the profitability of firms' innovative strategies (e.g. Boyer, 1988, Soskice, 1997, Eichengreen and Iversen, 1999). Indeed, labour market institutions can have an impact on both the size and appropriability of innovation rents. For instance, in industries where there is limited scope to expand production, technological change is likely to result in employment downsizing. Thus, institutions that make post-innovation employment adjustment more difficult or costly are likely to reduce innovation rents accruing to firms and hence innovative effort. Furthermore, implementing an innovation also requires shifting from one optimal mix of human and physical capital to another. The innovating firm can accomplish this task either by hiring new staff on the external market, possibly poaching on other firms' pool of skilled workers, or by training its own workforce. The specific nature of the technology of each industry has a bearing on the effectiveness of each of these strategies. Thus, the interplay among the knowledge base of different industries, regulations that limit the flexibility of the labour market and industrial relations systems that modify the incentives for firm-supported training is likely to affect the viability of different strategies, thereby partially shaping industry patterns of technological comparative advantage in different countries.

Cross-country evidence on the relationship between labour market institutions and innovation is relatively scarce and focuses mainly on comparisons between pairs of countries (US and Germany, US and Japan) ${ }^{1}$. On the contrary, this paper aims at providing broad cross-country econometric evidence on the association of innovation patterns and different labour market institutional regimes. To this end, we develop an empirical analysis of patterns of R\&D intensity in a cross-section of 18 OECD countries and 18 manufacturing industries.

Our results provide evidence that countries with a coordinated system of industrial relations tend to exhibit greater revealed technological comparative advantage in industries characterised by a highly cumulative knowledge base the more stringent the

\footnotetext{
${ }^{1}$ See e.g. Soskice (1997), Casper et al. (1999) and Casper and Glimstedt (2001).
} 
restrictions on hiring and firing. These results, we argue, can be related to the combination of two opposite forces. On the one hand, innovation may lead to downsizing or reshuffling of the workforce; therefore innovation is discouraged by legislation hindering labour adjustments. On the other hand, the more cumulative the innovation process, the larger the scope for resorting to internal labour markets and thus the lower the adjustment costs imposed by hiring and firing restrictions. Moreover, in the context of a cumulative and specific knowledge base, the combination of strict employment protection and coordinated industrial relations regimes, by aligning workers' and firms' objectives and encouraging firm-sponsored training as well as the accumulation of firmspecific competencies, allows firms to fully exploit the potential of the internal labour market.

The plan of the paper is as follows: in section 2 we discuss the main economic mechanisms that relate labour market institutions to innovative performance and map these mechanisms into differences across technological regimes characterising each industry in order to develop two working hypotheses that can be empirically tested. Empirical strategy and data issues are discussed in section 3. Section 4 develops the empirical analysis of labour market institutions and patterns of comparative advantage, while some concluding remarks are set forth in section 5 .

\section{Theoretical background}

\subsection{Labour market institutions, human resource strategies and innovation}

Labour market policies and institutions affect the scope for the firm to appropriate the rents generated through innovative activity. Additionally, these policies have a bearing on the size of innovation rents, through their impact on the cost of implementing innovations. In this subsection we discuss the interplay between labour market regulation and institutions in shaping the incentives for (and the viability of) different innovation strategies. In the next subsection these mechanisms will be mapped into technological regimes characterising sector differences.

Following Soskice (1997), we focus essentially on the potential impact of the flexibility of the labour market and the degree of coordination of industrial relations regimes. The system of industrial relations of a country can be defined by the set of bargaining institutions, business associations, and firm's code of conduct, prevailing in that country. An industrial relations system can be said to be coordinated when: (i) the 
wage-bargaining process is centralised or coordination among employers and/or trade unions sets a uniform band of wages; (ii) employers and trade unions cooperate as regard to decision-making inside the firm; and (iii) business associations (and/or a tacit code of conduct concerning firm behaviour) have an active role in solving free-riding problems across firms (e.g. training, standard-setting, fair competition, basic research).

\section{Wage re-negotiation}

Labour market arrangements, which increase the bargaining power of insiders or allow wage re-negotiation at the firm level after an innovation has been implemented, may reduce post-innovation profits, by making firms share innovation rents with workers. In decentralised systems of wage-bargaining, where wages are subject to re-negotiation at the firm level (at the time of contract renewal), a classical hold-up problem ${ }^{2}$ may occur, with firms partially restraining from undertaking innovative investment. Indeed, after successful innovation has taken place, the firm has already met with $R \& D$ expenditures and/or adoption costs. Therefore, to the extent that searching for new staff is costly, employed workers have a stronger bargaining power and can partially appropriate innovation rents.

By making labour turnover more difficult, employment protection adds to the bargaining power of insiders. It can be argued that strict hiring and firing regulations increase the leverage unions have at the firm level, hence worsening the rentappropriability problem when the wage can be negotiated after innovation has taken place. However reduced employment flexibility may have the opposite effect: longer tenure (which in turn is enhanced by less flexible labour markets) raises the time horizon of workers, who consequently might not try to maximise current wages, may limit their search for alternative jobs and be more inclined to work in innovative firms where, in the absence of employment protection, job security is smaller (Acemoglu, 1997a, 1997b).

The hold-up problem can be partly mitigated when bargaining, occurring at the national or industry level, pins down a general frame for the wage schedule. In such a case, the reservation wage is fixed for all lower-level bargaining units and is adjusted mainly in response to aggregate shocks. As a consequence, innovative investment by the firm no longer depends on the bargaining power of its own workers, allowing optimal investment. Co-ordinating individual bargaining processes at the industry or national

\footnotetext{
${ }^{2}$ See Malcomson (1997) for a review.
} 
level therefore partially solves the hold-up problem that may exist at the firm level, increasing incentives for innovation (Teulings and Hartog, 1998).

\section{Competence formation and training}

Employment protection provisions, industrial relations regimes (as well as the tax and benefit system) affect the quality and availability of skilled labour, which is a complementary input to new technologies. Different issues emerge here as regard to who is making the investment in human capital (who is paying for it) and what is the nature of the competencies to be acquired.

Skills of a general nature can be used in different firms and industries, and thus increase the market value of workers. Therefore, it has been argued that workers will pay for acquiring these skills (Becker, 1964). In this context incentives for the labour force to invest in education may be affected by the fact that wages in centralised/coordinated industrial relations systems are typically compressed over the skill dimension ${ }^{3}$. For instance, lower expected earnings for the upper range of skills may decrease expected returns to schooling and lead to a reduced participation of young people in tertiary education. However, higher contractual wage floors for low wage earners or statutory minimum wages dampen labour demand for unskilled workers and may consequently have incentive effects to prolong schooling and/or vocational education, leading to a more homogeneous but on average more educated workforce (Agell, 1999; Cahuc and Michel, 1996).

Firms too invest in general training. A firm has incentive to pay for training when wages are compressed over the skill dimension, so that it can reap the greater difference between the marginal productivity of skilled workers and their earnings, and when there is an economic mechanism preventing other firms from poaching on its pool of skilled workforce. As noticed above, coordinated systems tend to compress the wage distribution over the skill dimension. Furthermore, coordination provides at least two institutional arrangements that tend to inhibit poaching ${ }^{4}$ : (i) centralised and co-ordinated

\footnotetext{
${ }^{3}$ See Davis (1992), Blau and Kahn (1996), Blinder and Krueger (1996), Gottschalk and Smeeding (1997) and Kahn (1998) for evidence on compressed wage structure and centralisation/coordination of wage bargaining systems.

${ }^{4}$ Other mechanisms singled out by the literature are: lack of information on previous training of job candidates (Katz and Ziderman, 1990; Chang and Wang, 1996, Acemoglu and Pischke, 1998);
} 
wage-bargaining settings may extend contracts to cover almost all firms and workers and allow only limited variability of wage offers across firms, thereby dampening poaching since workers have no incentive to change job if no better wage offer can be made by the poaching firm (Teulings and Hartog, 1998; Acemoglu and Pischke, 1999b); and (ii) customary inter-firm practices, typical of co-ordinated industrial relations regimes, may enforce an equilibrium wherein poaching is considered as unfair behaviour ${ }^{5}$. Furthermore, the cost of training is often shared among employers when business associations have a prominent role (Soskice, 1997, Casper et al., 1999) ${ }^{6}$. Stricter employment protection legislation may add to these incentives to the extent that it depresses the quality of those in the unemployment pool (Acemoglu and Pischke, 1999a, Kugler and Saint-Paul, 2000).

Competencies can be also firm-specific. Firm-specific competencies increase the employee's productivity only inside the firm but not its outside market value. Becker (1964) argues that the firm pays for firm-specific training since, in principle, it can appropriate the returns to training because the worker cannot re-sell the acquired competencies elsewhere. If competencies can be taught through a formal course, the content of training is entirely controlled by the firm and the worker's behaviour is usually observed. However, a moral hazard problem may arise to the extent that the accumulation of competencies is not fully observable, as is often the case when they are acquired on the job. Indeed, the worker may try to acquire generic rather than firm-specific competencies, in order to increase its outside market value. Coordination between employers and trade unions may help setting a cooperative environment and align workers' and firm's objectives, because of workers' participation in firms' decisions and the establishment of an environment of mutual trust and loyalty. Furthermore, since the incentive to increase one's own generic human capital (at the detriment of firm-specific one) is larger the smaller the credibility of the career prospects within the same firm, stringent (statutory or

frictions and search costs (Acemoglu, 1997a, 1997b); and impossibility to separate general from firm-specific skills (Stevens, 1994; Acemoglu and Pischke, 1999a).

${ }^{5}$ For instance Blinder and Krueger (1996) report that inter-firm job mobility is virtually nonexistent in Japan due to firms' customary practices of refusing to employ people already working for other firms. Similarly Casper et al. (1999) report about legal provisions in Germany that reduce workers' mobility after training. Correspondingly, there is empirical evidence that there are no wage gains to switching jobs in Germany (Zimmermann, 1998) but they are substantial in the United States (McCue, 1996). Also, Blinder and Krueger (1996) report that many Japanese multinational firms have been forced to revise training strategies in their American affiliates due to poaching by competing firms.

${ }^{6}$ Lynch (1994), Blinder and Krueger (1996), Soskice (1997), Acemoglu and Pischke (1998, 1999a) and OECD (1993 and 2000) report scattered evidence of higher firm-sponsored training in more coordinated countries. 
contractual) employment protection complements these arrangements by introducing a commitment mechanism that enforces an otherwise time-inconsistent implicit contract.

\section{Labour turnover and employment downsizing}

Hiring and firing restrictions may increase implementation costs by hindering labour adjustments (e.g. downsizing and/or reshuffling of the workforce), which are often needed after innovations have been introduced (see e.g. Cappelli, 2000). Ceteris paribus the potentially negative effect of hiring and firing restrictions is stronger the smaller the scope for resorting to internal labour markets. As a matter of fact, in coordinated countries, for the reasons discussed above, firms tend to reallocate labour internally to a larger extent than in uncoordinated countries, thereby being less sensitive to the adjustment costs imposed by firing restrictions.

On the basis of this discussion, there is no a priori reason to expect a better innovation performance in a system of industrial relations than in another. Nevertheless, the complementarity between labour market regulation and coordination of industrial relations suggests that hiring and firing restrictions can be expected to be less negative (or more positive) the more coordinated the system of industrial relations. Figure 1 provides some suggestive evidence in favour of this hypothesis. In Panel A the logarithm of patent per capita is plotted against the indicator of stringency of employment protection legislation in countries with low or intermediate levels of coordination of the wagebargain. Two country clusters appear in the figure: English-speaking liberal countries and transition economies on the left and other countries (with intermediate levels of coordination) on the upper right corner. Correspondingly, two subgroup-specific downward-sloped lines can fit the relationships between employment protection and patent performance. By contrast, no systematic relationship appears between the same two variables in countries with high coordination (Panel B).

Figure 1 about here

\subsection{Technological Regimes}

Differences in the impact of labour market institutions across industries essentially emerge because the scope for reallocating resources internally rather than externally depends on industry specific features. 
On the one hand, if the scope for expanding production is limited (because the firm core activity is in industries characterised by product lines at the end of their lifecycles with a slow dynamics of demand), innovation will more frequently lead to downsizing, forcing firms to adjust externally. These industries are mainly low technology industries, with firms undertaking little in-house R\&D activity and mostly adopting technology produced elsewhere.

On the other hand, the more cumulative the innovation process, the greater the comparative advantage of using internally-developed competencies, and thus the stronger the incentive to resort to the internal labour market and the larger the gain allowed by (the lower the costs imposed by) coordination and employment protection.

Innovative activity is characterised by different patterns that are driven by technology properties and by the characteristics of the knowledge base necessary for generating innovations. We can therefore distinguish different technological regimes (Nelson and Winter, 1982) that map underlying characteristics of a technology onto patterns of innovative activity. A technological regime is defined by some essential features of the knowledge base and the prevailing learning conditions within an industry (Malerba and Orsenigo, 1995, 1997, 2000). Some of these features and conditions interact with labour market institutions and determine the effectiveness and viability of different human resource policies implied by different innovation strategies. In the following we will concentrate on three aspects of the knowledge base and learning conditions: (i) the scope of application of the knowledge base; (ii) its accessibility; and (iii) the degree of specificity of physical, organisational and human capital assets at the individual and firm level.

The scope of the knowledge base indicates the degree to which new knowledge can be applied to a variety of activities or is specific to a particular application. A wide scope means that the knowledge base relies on a broad general understanding of technological relations that can then be recombined in different ways in each new innovative venture. Conversely, narrowly focused knowledge, mostly the result of expertise in applied science, has essentially specialised applications allowing innovations as the outcome of continuous development of the same competencies. Industries characterised by a large scope of the knowledge base continually create opportunities for new firms (or existing firms from other sectors) to enter the market while a smaller scope 
of the knowledge base favours incumbents and concurs in creating conditions for stable technological leadership (Malerba and Orsenigo, 1995, 1997, Breschi et al., 2000).

The accessibility of the knowledge base is defined by the opportunity to gain knowledge external to the firm. New entry into a given market will be larger the more accessible for outsiders the knowledge required to compete neck-and-neck. In such a case, potential competitors may learn about the new product or process and imitate it, thus rapidly reducing innovation rents for incumbents. Also, an existing firm may easily diversify into new areas when their knowledge base is accessible (Malerba and Orsenigo, 2000). Similarly, firms in one industry may sometimes take advantage of the expansion of the knowledge base of another industry to the extent that the latter is accessible.

The degree of specificity of competencies and organisational structures is one of the main sources of cumulativeness of the innovation process. Knowledge and competencies are firm and individual-specific when they are too costly (or technically impossible) to be codified (and transferred) and/or when system components (human capital, physical capital and organisational routines) are complementary and cannot be changed piecewise (Nelson and Winter, 1982, Kitschelt, 1991). Furthermore, knowledge and competencies can be firm (or network) specific when they are embedded in complex organisational routines (March and Simon, 1958, Nelson and Winter, 1982, Dosi, 1988, Dosi and Coriat, 1998). When competencies are specific "today's knowledge forms the starting point of tomorrow's knowledge advancements" (Malerba and Orsenigo, 2000, p.302) and firms have a comparative advantage in developing along their established technological trajectory.

Two main technological regimes can be distinguished: Schumpeter Mark I (Nelson and Winter, 1982) or entrepreneurial (Audretsch, 1995) characterised inter alia ${ }^{7}$ by low specificity, low cumulativeness, large scope and accessibility of the knowledge base; and Schumpeter Mark II or routinised characterised by high specificity, high cumulativeness, small scope and scarce accessibility of the knowledge base.

In industries characterised by a prevailing entrepreneurial technological regime, firms often undertake sequences of short-lived projects based on the same general knowledge but different specific realisations (e.g. as a consequence of short life-cycles of

\footnotetext{
${ }^{7}$ See Malerba and Orsenigo $(1995,1997)$ for an exhaustive characterisation of technological regimes.
} 
products and rapid capital depreciation as in the case of the standardised software industry). In this process, they rely on unique combinations of human and physical capital requiring (or at least not being impaired by) a quick turnover of workers (or even firms themselves), as newly hired personnel brings in new ideas and allows substituting for older organisational routines. Large accessibility of knowledge implies that newly hired staff can easily learn specific applications to the extent that they share a common broad knowledge base. In brief, in industries characterised by an entrepreneurial technological regime the scope for the internal labour market is limited.

In industries characterised by a routinised technological regime, conversely, the best available competencies for incremental innovations along an existing trajectory may well be inside the firm itself. Due to the specificity of competencies and the complexity of the relationships among system components, the loss of few staff members may involve significant costs for the firm, while newly hired staff have to spend time and make effort in learning specialised routines before becoming fully operational. So, in routinised technological regimes incentives to use the firm's internal labour market are greater.

Coupling the discussion of this section with that of the previous one, it seems natural to expect that industries with a routinised technological regime loom large in countries where the institutional arrangements in the labour market favour the exploitation of the internal labour market. Similarly, industries characterised by an entrepreneurial technological regime tend to flourish in countries characterised by a flexible labour market. ${ }^{8}$ This leads us to formulate two testable hypotheses:

i. Direct effect: Countries with a coordinated (resp. uncoordinated) industrial relations system have a technological comparative advantage (resp. disadvantage) in industries characterised by a routinised technological regime (routinised industries hereafter) and a comparative disadvantage (resp. advantage) in industries characterised by an entrepreneurial technological regime (entrepreneurial industries hearafter).

\footnotetext{
${ }^{8}$ Studies based on the comparison between Germany and the United States actually provide some empirical evidence confirming these conclusions (Soskice, 1997, Casper et al. 1999, Casper and Glimstedt, 2001).
} 
ii. Complementarity effect: Countries with a coordinated industrial relations system have a greater technological comparative advantage in industries with a routinised technological regime and a smaller comparative advantage in low-technology industries (characterised by smaller scope to expand production) the greater the level of employment protection.

To anticipate our empirical results, on the basis of $R \& D$ data for 18 countries and 18 manufacturing industries, we find strong evidence supporting the complementarity hypothesis while only limited evidence is found in support of the direct one. Although the lack of conclusive evidence concerning the direct effect hypothesis might reflect data problems, we interpret these results as an indication that coordination alone does not suffice to enhance comparative advantage in routinised industries. One explanation can be that, in these industries, it is the interplay between the degree of coordination and the commitment mechanism inherent to stringent employment protection that allows firms to develop their core competencies through an effective exploitation of internal labour markets.

\section{Methodology and data}

\subsection{The empirical framework}

Following a large empirical ${ }^{9}$ and theoretical literature ${ }^{10}$, the simplest possible model of the determinants of innovative effort relates the latter to the expected profit differential - that is the expected difference between profits that the firm can earn once it has successfully innovated and profits that would be earned otherwise. In turn, the expected profit differential depends on market structure, industrial relations and other factors, including the dynamics of industry's domestic and world demand, minimum efficiency scale and prevailing capital intensity, the extent of knowledge spillovers, technological opportunity ${ }^{11}$, appropriability conditions, accessibility of knowledge, cumulativeness of knowledge. Furthermore, we assume that market structure and industrial relations are the outcome of existing institutions (and regulation) in the product and labour market ${ }^{12}$. Taking the ratio of business-performed $R \& D$ expenditure to sales

\footnotetext{
${ }^{9}$ see e.g. Geroski (1990) and Aghion et al. (2001b).

${ }^{10}$ see e.g. Aghion et al. (2001a) and Boone (2000) for recent examples.

11 Technological opportunity can be defined as the easiness of successfully innovating for any given amount of resources invested.

${ }^{12}$ Political economy considerations are beyond the scope of this paper. On that see e.g. Duso and Röller (2001).
} 
( $R \& D$ intensity hereafter) as the indicator of innovative activity, we can write the following reduced form equation:

$$
R \& D=f(\text { LMR, PMR, OTHER })
$$

where $R \& D$ stands for R\&D intensity, $\mathbf{L M R}$ and PMR for vectors of indicators of labour and product market regulation (and/or institutions) respectively, and OTHER is a vector of other variables including controls for technological opportunity.

The main thrust of this paper is to assess the role of the interplay between labour market institutions and technological regimes in shaping the innovation patterns of a country. Nevertheless the effect of labour market institutions is often reputed a secondorder effect that cannot be assessed without taking into account the institutions in the product market, particularly in the view of the strong statistical correlation between indicators of labour and product market regulation in OECD countries ${ }^{13}$. For this reason, in this paper, great care is devoted to control for different aspects of product market regulation.

In the following, equation [1] is implemented empirically on a cross-section of 18 manufacturing industries and 18 OECD countries. Labour market institutions are summarised by dummies concerning the industrial relations regime (uncoordinated vs. coordinated regimes) and a cardinal indicator of the strictness of employment protection legislation (EPL hereafter), which we take as a proxy for labour market rigidity. In order to test the hypotheses spelled out in section 2.2, the coefficient of EPL is allowed to vary between coordinated and uncoordinated countries through interactions with the industrial relations dummies. As indicators of product market regulation we use measures of inward-oriented economic regulation (state control, legal barriers to entry, price controls, etc...), administrative regulation (administrative barriers on start-ups, features of the licensing and permit system, etc...), indicators of tariffs and non-tariffs barriers, plus an indicator of global protection of Intellectual Property Rights (IPRs hereafter). Furthermore, we use import penetration both as a control for competitive pressures not captured by the regulatory indicators and as a proxy for international technological spillovers, the intuition being that trade openness increases product variety in domestic markets and induces imitation by domestic producers, which in turn requires spending in R\&D (Cohen and Levinthal, 1989). Finally, most of the other factors can be controlled

\footnotetext{
${ }^{13}$ See for example Nicoletti et al. (1999).
} 
for either by industry dummies (technological opportunity, returns to scale, dynamics of industry's world demand, etc.) or by country dummies (aggregate demand, supply of human capital, etc.). However, other co-variates (such as capital intensity and the dynamics of industry's domestic demand), being co-determined in equilibrium, are not included in the reduced form since, in a cross-section, it is impossible to find valid instruments for these variables. ${ }^{14}$ A control for the average size of firms represents an exception. In fact, this control captures the bias in R\&D intensity across industries and countries due to different accounting practices between large and small firms and has been proved to play an important role (see e.g. Griliches, 1990, Geroski, 1990). The robustness of the results is however tested by dropping the size variable.

Choosing a log-linear form for convenience, equation [1] can be therefore rewritten as:

$$
\log R \& D_{i j}=\alpha+\sum_{k} \beta_{k} L M R_{i j}^{k}+\sum_{h} \gamma_{h} P M R_{i j}^{h}+\delta I M P_{i j}+\phi S I Z E_{i j}+\mu_{i}+\chi_{j}+\varepsilon_{i j}
$$

where IMP and SIZE denote import penetration and average size, $\mu$ stands for the country dummy, $\chi$ stands for the industry dummy, $\varepsilon$ is the standard error term, while $k, h, i$ and $j$ index labour market institutional variables, product market regulatory indicators, countries and industries, respectively.

Statements on the comparative advantage of different institutional systems can be derived from tests of hypotheses in this framework. In the case of balanced samples, a standard indicator of revealed technological comparative advantage is:

$$
C_{i j}=\frac{R \& D_{i j} / R \& D_{i_{-}}}{R \& D_{-j} / R \& D_{--}}
$$

where the underscore denote the average over the corresponding country (industry) dimension. A monotone transformation of equation [3] is the following:

$$
\log C_{i j}=\log R \& D_{i j}-\log R \& D_{i_{-}}-\log R \& D_{-j}+\log R \& D_{-,-}
$$

Plugging equation [2] into equation [4] we have:

\footnotetext{
${ }^{14}$ Furthermore, we lack good cross-country comparable data on capital intensity both at the aggregate and industry level. Obviously this shortage limits the scope of the empirical analysis,
} 
$\log C_{i j}=\mathrm{A}+\sum_{k} \beta_{k} L M R_{i j}^{k}+\sum_{h} \gamma_{h} P M R_{i j}^{h}+\delta I M P_{i j}+\phi S I Z E_{i j}+\mathrm{M}_{i}+\mathrm{X}_{j}+\varepsilon_{i j}$

where $\mathrm{A}=\log R \& D_{--}+\alpha, \quad \mathrm{M}_{i}=\log R \& D_{i_{-}}+\mu_{i}$ and $\mathrm{X}_{j}=\log R \& D_{-}+\chi_{j}$. Hence, the slope coefficients of equation [2] can be interpreted as slope coefficients of equation [5] wherein the dependent variable is the indicator of comparative advantage $\log C_{i j}$. Equation [2] can therefore be used to estimate the relationship between institutional variables and revealed comparative advantage, except that the interpretation of the estimated coefficients of country and industry dummies is different. The advantage of using equation [2] rather than equation [5] is that the former does not involve measures of $R \& D$ averages, which are not available in the case of unbalanced samples. In practice, the estimation of the slope coefficients using a specification like equation [2], which allows controlling for country and industry effects, corrects for biases due to missing observations.

In section 4, using the sector taxonomy discussed in the previous section, we examine how the technological comparative advantage in a given sector depends on national institutional variables. In practice, this involves testing for differences in the coefficients of institutional variables across different clusters of industries and industrial relations systems. This will be accomplished by multiplying indicators of institutions and regulations by dummies characterising sector types. For instance, finding the coefficient of the dummy for coordinated countries greater when multiplied by a dummy for routinised industries than when multiplied by a dummy for entrepreneurial industries will be interpreted as evidence of the direct effect hypothesis (that implies a comparative advantage in routinised industries for coordinated countries).

Aggregate and semi-aggregate models of the type used in this paper can be extremely sensitive to few outliers and influential observations usually due to measurement errors or specific omitted variables (see e.g. Scarpetta, 1996, Temple, 1999, 2001). For this reason we use multiple techniques for the identification and elimination of outliers and influential observations that are based on leverage and residual of each observation $^{15}$.

which falls short of fully identifying the underlying economic mechanisms and therefore cannot provide a complete test of the theoretical hypothesis.

${ }^{15}$ The simplest possible indicator that we could use is the studentised residual of each observation $i$, which corresponds to the t-statistic of a dummy variable for $i$ that has been added to the original regression equation. Although appealing and quite intuitive, this statistic tends to eliminate 


\subsection{Data issues}

Our sample includes all manufacturing industries at 2-digits of the ISIC Rev.3 classification except that Manufacturing not elsewhere classified (ISIC 36 and 37), being a residual sector, has been excluded, while Food, beverages and tobacco (ISIC 15 and 16) and Textiles (ISIC 17, 18 and 19) have been aggregated due to lack of data availability. Countries considered, again due to data availability, are Austria, Belgium, Canada, Germany, Denmark, Finland, France, Greece, Ireland, Italy, Japan, the Netherlands, Norway, Portugal, Spain, Sweden, the United Kingdom, and the United States. When controls for firm size are not included in the regressions, Australia can be added to the sample and has been indeed added in some of the sensitivity analysis (see below). If not differently specified, all variables have been averaged across 1993-1997, excluding years in which observations for most of the industries were missing. Descriptive statistics of all variables are reported in the appendix, while in this section we discuss data sources and limitations.

$R \& D$ intensity is defined as the ratio of Business Expenditure in Research and Development (BERD) to output. Data on industry-level BERD are drawn from the OECD ANBERD database, except in the case of Austria, for which the OECD R\&D database was used. Data on industry output are the result of the harmonisation of different sources (OECD STAN Database - edition 2000, OECD Annual National Accounts Database, OECD Industrial Structure Statistics - ISIS). Data on the ratio of government-financed BERD to total BERD (used only in the sensitivity analysis) are from the OECD R\&D database.

The advantage of using R\&D intensity data is that they are available for many countries on a comparative basis. Nevertheless, it must be borne in mind that the use of $R \& D$ intensity as an indicator of innovation suffers from important limitations (for a

observations with large residual but low leverage that do not influence the estimated coefficient very much (that is in the case where their dummy variables are orthogonal to the other regressors), biasing upwards goodness-of-fit statistics. Other more complex indicators are based on the notion of influence curve. The influence curve assesses the asymptotic marginal effect on the coefficient estimates of adding a specific observation $i$, on the basis of the original regression model. The influence curve is only an asymptotic concept. In this paper, however, we use two indicators, the DFITS or Welsch-Kuh distance and the Welsch distance, that try to approximate empirically the influence curve and detect influential observations from that. Finally, other indicators assess the effect of adding one specific observation on the estimated confidence ellipsoids: among these, the covariance ratio is equal to the ratio of the determinants of the coefficients' variance-covariance matrices with and without the additional observation. Values far from 1 are taken to signal influential observations (see Chatterjee and Hadi, 1988). 
general discussion, see Griliches, 1990). R\&D intensity is an indicator of input in the innovative process rather than output. Consequently improvements in the efficiency of the innovation process (greater output with less input) can be mistakenly interpreted as a reduction of the innovative effort. Moreover, $R \& D$ intensity conveys only information about formal innovation expenditure. In many industries informal innovation is a sizeable component of overall innovation activity. Also, reported data tend to overestimate $R \& D$ intensity of large incumbents relative to small firms and new entrants. Small firms typically undertake much informal $R \& D$ and are not included in the $R \& D$ statistics if they do not have at least one full-time research employee. In the case of entrants, expenditure made before entering the industry is generally not recorded or might be recorded in other industries.

Import penetration is defined as the ratio of total imports to apparent demand. Data on imports are from OECD Foreign Trade Statistics. Consistent with the computation of $R \& D$ intensity, the data on output used in the computation of apparent demand are the result of the harmonisation of different sources (OECD STAN Database edition 2000, OECD Annual National Accounts Database, OECD Industrial Structure Statistics-ISIS). Data on the employment share of foreign enterprises (used only in the sensitivity analysis) are from the OECD AFA Database and refer to 1996.

Data on firm size are from the OECD SME Database. Common size classes have been reconstructed on the basis of available raw information on total employment. Furthermore, firms with less than 10 employees have been excluded due to concerns on the quality and comparability of the corresponding data. Consequently, only total employment for two size classes is available on a comparable basis (firms with 10 to 49 employees and firms with 50 or more employees). The final measure used in the regression analysis is the ratio of total employment of firms with 50 or more employees to total employment of all firms in the sample. In the case of Canada dependent employment is used instead of total employment, due to lack of data for total employment. Experimentation on countries where both total and dependent employment are available showed that regressing total employment shares on dependent employment shares leads to a unitary coefficient and a non-significant constant. Thus, no bias seems to be introduced by this approximation.

Data on trade barriers are from the OECD Indicators of Tariff \& Non-tariff Trade Barriers and refer to 1996. Tariffs are defined as the simple average of ad valorem 
tariff rates applied to the most favoured nation. The indicator of non-tariff barriers is a frequency ratio: it corresponds to the proportion of tariff lines to which anti-competitive non-tariff barriers apply. To avoid tariff measures being non-representative, observations in which the frequency ratio of non-ad valorem tariffs is greater than 20 per cent (Coke, refined petroleum and nuclear fuel - ISIC 23 - in Japan; Other non-metallic mineral products - ISIC 26 - and Telecommunication equipment - ISIC 32 - in Norway) are dropped from the sample.

The indicator of protection of IPRs has been developed by Ginarte and Park (1997). It varies between 0 and 5 from least to most stringent. The data used in this paper refer to 1995 and have been kindly supplied by Walter Park. All other regulatory indicators (administrative regulation, anti-competitive inward-oriented economic regulation, and EPL) are from Nicoletti et al. (1999). They vary between 0 and 6 from least to most restrictive and refer to 1998 (except EPL that is averaged over 1993-1997).

The classification of countries as regard to the degree of coordination of their industrial relations system is based on the OECD indicator of the level of coordination of the wage-bargain (Elmeskov et al., 1998). This indicator classifies countries into three groups (low, intermediate, and high coordination). Due to the small number of countries in the low coordination group, these countries are grouped together with intermediate coordination countries, and they will be called decentralised hereafter.

With the exception of indicators of tariffs and non-tariff barriers and inwardoriented economic regulation, all other regulatory and institutional indicators refer to economy-wide regulation and institutions that are by definition identical across industries in each country and therefore cannot be identified in the presence of country dummies. Moreover, the same applies to the indicator of inward-oriented economic regulation for which no sector breakdown is available, leading us to proxy it with an economy-wide indicator. For this reason, in the following empirical analysis, these variables appear only interacted with other variables, level effects being already controlled for by country dummies.

Descriptive statistics of all variables are reported in Table A1 in the appendix. In that table, as well as in the remainder of the paper, "high-tech" ${ }^{16}$, "low-tech",

\footnotetext{
${ }^{16}$ Throughout the paper high-tech industries refer to high and medium-high technology industries according to the OECD classification (Hatzichronoglou, 1997).
} 
"routinised" and "entrepreneurial" indicate dummies for high-technology, lowtechnology, routinised and entrepreneurial industries, respectively. Similarly, "coordinated" and "decentralised" denote dummies for coordinated and decentralised industrial relations systems, respectively.

\section{Empirical results}

\subsection{Main results}

We start our analysis by using a standard classification of industries (high-tech, low-tech) that will be refined later on to take into account differences in technological regimes. Table 1 reports the results from the estimation of a baseline specification including trade barriers, size and import penetration, as well as interaction terms between labour market institutional variables and a dummy for high-technology industries. As discussed, due to the presence of country dummies, the coefficient of institutional variables that are identical across industries within countries cannot be identified. Conversely, the interactions of these variables with dummies characterising industry types can be identified if at least one industry-type dummy is omitted. Hence, in the presence of country dummies, all the estimated coefficients of these interaction variables must be interpreted in terms of differences from a benchmark (the omitted industry type), which in this paper is represented by low-technology industries. However, since comparative advantage is by definition a relative concept, this suffices to meet the goal of estimating the impact of institutional variables upon comparative advantage in one industry type (with respect to another one). For example, in Table 1, the coefficients of the interactions with the high-tech dummy must be interpreted as representing differences between the estimated effects of labour market institutions in high-tech and low-tech industries. A positive and significant coefficient of any given variable in high-tech industries means that the greater that variable the greater the estimated comparative advantage in high-tech industries.

Table 1 about here

Column 1 of Table 1 reports unweighted estimates of this baseline specification. The same specification is then re-estimated by weighting industries by their average employment size across countries and the corresponding results are presented in column 2. Results obtained after eliminating influential observations identified through the asymptotic Welsch distance cut-off and the Welsch-Kuh distance cut-off combined with 
the covariance ratio (see Chatterjee and Hadi, 1988 and footnote 15) are reported in columns 3-4 and 5-6, respectively ${ }^{17}$. We also tried augmented specifications including the ratio of government-financed BERD to total BERD and the employment share of foreign enterprises (not shown in the table). However, coefficient estimates of these variables never turned out significant (even when controlling for outliers), without changing the significance of other coefficients. Given that our sample size drops to 180-190 observations when adding these controls, we did not include them in further refinements of the specification.

The importance of controlling for influential observations is shown by the RESET test statistics. In column 1 the statistic shows evidence of misspecification at the $5 \%$ confidence level. It is however sufficient to weigh industries by their average employment across countries (column 2) to obtain a better statistic, suggesting that its value might be driven by smaller industries where typically data quality is lower and omitted idiosyncratic effects more important. Columns 3-4 confirm this fact, by showing that it is sufficient to eliminate 8 observations (over 265) ${ }^{18}$, that are singled out by the asymptotic Welsch distance cut-off as being particularly influential, to make the test statistic insignificant. Moreover, the latter result is robust to further elimination of observations by using tighter statistical cut-offs (as shown in Columns 5-6).

Controls for size and import penetration have the expected sign and significance. A negative estimated coefficient of non-tariff barriers is also robust across all specifications. Conversely, the estimated coefficient of tariff barriers is positive, although not significant. This might be due to controlling for import penetration (which captures some aspects of competitive pressure) and the lack of variability of the indicator resulting from the fact that trade barriers are the same across all EU countries.

\footnotetext{
${ }^{17}$ Since heteroskedasticity tests show some evidence of exponential heteroskedasticity with respect to size, import penetration and tariffs, all specifications in Table 1 and 2 are re-estimated by taking logarithms of these three variables. All the results are robust to this change in specification, which in addition yields better RESET test statistics and a smaller number of outliers. Full regression results with $\log$-log specifications are available from the authors upon request.

${ }^{18}$ These observations are Food, beverages and tobacco (ISIC 15-16) in Norway, Computers (ISIC 30), Telecommunication equipment (ISIC 32) and Wood (ISIC 20) in Ireland, Other transport (ISIC 35) in Greece, Coke, petroleum and nuclear fuel (ISIC 23) in the United Kingdom, Motor vehicles (ISIC 34) in Belgium and Electrical Machinery (ISIC 31) in the Netherlands.
} 
Nonetheless, according to Boone (2000) there might be good theoretical reasons for less negative impact of tariffs (than of non-tariff barriers) on innovation ${ }^{19}$.

In coordinated countries, the estimated coefficient of the product of EPL by a dummy for high-tech industries and a dummy for coordinated industrial relations regimes (that is the estimated coefficient of the interaction indicated as $E P L^{*} h i g h$ tech $*$ coordinated in Table 1) is positive and significant. In other words, results in Table 1 suggest that coordinated countries with high EPL have a greater technological comparative advantage in high-tech industries (as opposed to low-tech industries) than coordinated countries with low EPL. Conversely, in decentralised countries, we find little difference between the effects of EPL in high and low-tech industries.

These results could merely reflect the fact that in coordinated economies firms adjust less frequently on the external labour market when the dynamics of demand is such that an innovation can be followed by output expansion and no employment contraction (which is often the case in high-tech industries). However, on the basis of the theoretical discussion made in the previous section, it is legitimate to suspect that the results for EPL are also due to the fact that no further distinction is made in Table 1 between industries characterized by different technological regimes. In practice estimates of Table 1 suffer from misspecification to the extent that high-tech industries characterised by entrepreneurial and routinised regimes are grouped together.

To go further down the road of technological regimes and labour market regulation, we need a mapping classifying our 2-digit industries into their corresponding regime. A specific measure of the degree of "routinisation" (as opposed to "entrepreneurship") is provided by Malerba and Orsenigo (1997) and Breschi et al. (2000). Their principal component indicator characterises 26 technological classes (obtained through aggregation of 12-digit International Patent Classification classes) that account for about two-thirds of total patenting activity in the major European countries.

\footnotetext{
${ }^{19}$ Under Cournot competition in partial equilibrium, conditional to the level of knowledge spillovers, tariffs have a positive impact on profits because they add to competitors' costs without changing the incentive to reduce own costs via innovation. However, in general equilibrium, tariffs interact negatively with imports and might then have a negative overall impact due to their indirect effect on knowledge spillovers. Conversely, non-tariff barriers have a greater impact on the diffusion of products and, eventually, the possibility of imitation and reverse engineering by domestic firms. Moreover high non-tariff barriers can be thought to directly affect the elasticity of substitution between imported and domestically produced products, thereby inducing low incentives to innovate when domestic and foreign firms have similar levels of competitiveness (the case of "neck and neck" competition).
} 
This indicator allows the authors to map these classes into routinised, entrepreneurial and mixed regimes. Since virtually all high-tech 2-digit industries are composed of technological classes belonging to different regimes an exact mapping with ISIC Rev.3 2digit industries is not readily available. Three industries represent however an exception (Telecommunication equipment ${ }^{20}$ - ISIC 32 -, Computers - ISIC 30 - and Motor vehicles ISIC 34) and can be classified as routinised. We add Other transport (ISIC 35) to this group, because Aircrafts and spacecrafts, a technological class unambiguously classified as routinised (see e.g. Malerba and Orsenigo, 1997, and Marsili, 2001), accounts on average for over 60 per cent of all R\&D expenditure of this industry (with a median of 75 per cent). In contrast, we can place the remaining 4 high-tech industries (Chemicals, including drugs - ISIC 24 - Machinery not elsewhere classified. - ISIC 29 - Electrical machinery - ISIC 31- Precision and optical instruments - ISIC 33) under the heading of "prevailing entrepreneurial regime". Full regression results from the specification of Table 1 augmented by grouping high-tech industries according to this classification are reported in Table 2, while, correspondingly, Table 3 reports differences between estimated coefficients involving EPL ${ }^{21}$.

Table 2 about here

Table 3 about here

The main result that emerges from Tables 2 and 3 is that in coordinated countries EPL is significantly associated with a revealed comparative advantage in routinised industries with respect to both low-tech and entrepreneurial industries. Indeed, the estimated coefficient of the interaction EPL*routinised*coordinated is significantly positive and greater than the estimated coefficient of the interaction EPL*entrepreneurial ${ }^{*}$ coordinated $^{22}$. The reverse is true for decentralised countries, although often not significantly.

\footnotetext{
${ }^{20}$ Including also most of electronic components.

${ }^{21}$ The tables report both unweighted and weighted estimates, with different controls for influential observations.

${ }^{22}$ As discussed, due to the presence of country dummies, all the estimated coefficients of interaction variables are expressed with respect to a benchmark, which in all the tables of this paper is represented by low-tech industries. For instance, the estimated coefficient of the interaction variable EPL*routinised*coordinated must be interpreted as representing, for coordinated countries, an estimate of the difference between the effects of EPL on R\&D intensity in routinised and low-tech industries.
} 
Consistently, results in Table 3 show that there is a structural difference between coordinated and decentralised countries in the relationship between EPL and revealed comparative advantage in routinised industries. More precisely, estimates reported in Table 3 shows that: a) the difference between the coefficients of the interactions EPL*routinised*coordinated and EPL*routinised*decentralised is positive; and b) this difference is greater than the difference between the coefficients of the interactions EPL ${ }^{*}$ entrepreneurial ${ }^{*}$ coordinated and EPL*entrepreneurial*decentralised ${ }^{23}$. Both results are significant at the $1 \%$ level when influential observations are controlled for. In simpler words, these results mean that EPL enhances comparative advantage in routinised industries (with respect to both low-tech and entrepreneurial industries) to a significantly greater extent in coordinated countries than in decentralised countries (where the effects of EPL on comparative advantage are limited). Overall, these results yield strong support to the complementarity hypothesis discussed in section 2.2.

The estimated coefficients of the interaction variables involving EPL and a dummy for entrepreneurial industries are generally not (or weakly) significant, suggesting that EPL does not affect comparative advantage between entrepreneurial and low-tech industries. This is also not surprising in the view of the theoretical discussion of the previous sections, given the limited scope for internal labour markets in both entrepreneurial and low-tech industries, albeit for different reasons.

We can also try to assess the effect of coordination per se on patterns of comparative advantage (the direct effect hypothesis of section 2.2). To do so we need to simulate the effect of coordination for a given level of employment protection. More precisely, the estimated effect of coordination for a given industry type (with respect to the low-tech benchmark) can be obtained as the sum of the estimated coefficient of the dummy for that industry type in coordinated countries (that is the coefficient of the interaction industry type*coordinated in Table 2) and the difference between the estimated coefficients of EPL for that industry type in coordinated and decentralised countries (EPL*industry type*coordinated minus EPL*industry type*decentralised in Table 2) multiplied by a chosen value of EPL. In Table 4 derived coefficients are shown

\footnotetext{
${ }^{23}$ These two results mean that, as regard to the estimated impact of EPL, there is significant evidence that: a) the difference between routinised and low-tech industries in coordinated countries is greater than the difference between routinised and low-tech industries in decentralised countries; and b) the difference between routinised and entrepreneurial industries in coordinated countries is greater than the difference between routinised and entrepreneurial industries in decentralised countries.
} 
with reference to the median and the third quartile of the distribution of EPL ( 2.41 and 3.08, respectively). At a median level of the indicator of EPL there is some limited evidence that coordinated countries have a comparative disadvantage in entrepreneurial industries with respect to low-tech industries. Conversely, the difference between the effects of coordination in entrepreneurial and routinised industries (not shown in the table) is never significant. This suggests that, due to the complementarity between employment protection and coordination, significant differences in the patterns of technological specialisation exist only in the presence of stringent regulation. Indeed, at the third quartile of the distribution of the indicator of EPL, coordinated countries show significant evidence (at the 5 per cent level upon exclusion of outliers) of comparative advantage in routinised industries with respect to both low-tech and entrepreneurial industries.

Table 4 about here

\subsection{Sensitivity analysis}

Variation of country coverage

It could be argued that in small country samples, one individual country could significantly affect the estimated parameters. In our case this problem might be particularly relevant. Indeed, on the one hand, the indicators that we use to identify industrial relations regimes are somewhat crude (see among others Flanagan, 1999) and the classification of some countries can be questioned for different reasons ${ }^{24}$. On the other hand, the distribution of routinised and entrepreneurial subsectors of any given industry may vary across countries (for instance the Aircraft and aerospace industry is virtually absent in Denmark and Portugal). A sensitivity analysis was thus performed on our preferred specification (corresponding to Column 2 of Table 2) in order to assess the robustness of results to variation of country coverage, by eliminating one country at a time and re-running the estimation procedure. Figure 2 reports the results of the sensitivity analysis on the different tests of hypotheses on comparative advantage discussed above with reference to Tables 2 and 3. Panel A concerns patterns of comparative advantage in coordinated countries and the t-statistics refer to, namely, i) the

\footnotetext{
${ }^{24}$ The indicators are based on wage-bargaining institutions and take into account only in a limited way other aspects of industrial relations regimes. For instance, in contrast with our indicator, Soskice (1997) and Casper and Glimstedt (2001) tend to classify Sweden among the co-ordinated countries.
} 
difference between the estimated effects of EPL in routinised and low-tech industries (that is the coefficient of the interaction EPL*routinised*coordinated); and ii) the difference between the estimated effects of EPL in routinised and entrepreneurial industries. In Panel B, t-statistics refer to tests for structural differences in the way EPL affects comparative advantage between coordinated and decentralised countries. In all these cases t-statistics above 1.65 (horizontal line in the figure) or 1.97 are consistent with our previous results at the 10 per cent or 5 per cent level, respectively.

\section{Figure 2 about here}

Figure 2 shows that two countries (Denmark and Italy) seem to affect regression outcomes in opposite ways. The elimination of Italy from the sample reduces the significance of some of the tests on the impact of EPL on comparative advantage to below the 5 per cent confidence level (but still above the 10 per cent threshold). Conversely, the significance of these tests is boosted by the elimination of Denmark. Anyway, the simultaneous elimination of both Denmark and Italy has perfectly offsetting effects, thereby confirming the overall robustness of our main results.

We challenged further the results presented above by including other variables in the specification. In particular, we tested whether there is evidence that the pattern of comparative advantage is associated with either administrative regulation or inwardoriented economic regulation or protection of intellectual property rights. At the same time, we checked whether the inclusion of these variables changes the results concerning labour market regulation. As shown by the estimates reported in Table 5, both specification and results shown in Table 2 are confirmed by the outcome of this sensitivity exercise. On the one hand, no economy-wide product market regulation variable seems to be associated with the pattern of $R \& D$ specialisation in different technological regimes. On the other hand, allowing the estimated coefficients of regulatory variables to vary across different industry groups does not change the evidence on comparative advantage discussed above.

Table 5 about here

Finally, average firm size (or any variable that can proxy for it) is an endogenous variable that typically is positively affected by R\&D intensity (e.g. Dasgupta and Stiglitz, 1980, Sutton, 1998). Although, as discussed in section 3, there are good reasons for including this control, to the extent that regulation and institutions are 
correlated with firm size, including this variable in the regression may bias the estimates of the parameters of interest. Nevertheless, excluding firm size from the regression, we obtain identical results in terms of both sign and significance as well as tests of hypotheses ${ }^{25}$.

\section{Classification of industries}

The classification of the 4 industries we placed under the heading of "prevailing entrepreneurial regime" is not thoroughly satisfactory ${ }^{26}$. In order to check the robustness of the results a sensitivity exercise can be run by means of shifting one industry at a time to the other group. Alternatively, we can choose a more conservative approach and, by using a more qualitative argument, single out those two-digit industries that are unambiguously characterised by a complex organisation of firms and a complex learning process (such as Automobiles and Aircrafts and spacecrafts). As noticed by Kitschelt (1991), Audretsch (1995) and Marsili (2001), these industries are classical examples of a routinised regime, insofar they are characterised by a cumulative pattern of technological change and organisations that cannot be easily changed piecewise. This would lead us to classify Motor vehicles and Other transport as routinised and, by contrast, group together all other 6 high-tech industries. No substantial difference in both sign and significance of

\footnotetext{
${ }^{25}$ Sample size increases to 298 observations (without controlling for outliers) when no control for firm size is included in the specification. Moreover it is increased further when Australia, for which no data on firm size exist, is included. However all our results are robust to the inclusion of this country into the sample. Regression results are available from authors.

${ }^{26}$ A large amount of the R\&D activity of the Chemicals industry is done by the pharmaceutical industry - an entrepreneurial industry according to the principal component indicator of Breschi et al. (2000). This suggests that it might be appropriate to classify this industry in the "prevailing entrepreneurial regime" group, although other chemical productions are better characterised as routinised. Similarly most of the Electrical machinery and Precision and optical instrument can be associated with technological classes characterised by entrepreneurial regimes, except that transformers and switchers (being part of the electronic components class) and optical instruments and photographic apparatus are rather characterised by a routinised regime. The classification of Machinery not elsewhere classified (ISIC 29) is even more complex. On the one hand a large set of its subsectors corresponds to the technological classes of Household electrical appliances, Industrial automation and to part of Industrial machinery that the principal component indicator classify as entrepreneurial. On the other hand, Engines and turbines (ISIC 2911), and Pumps (ISIC 2912), that are among the largest 4-digit subsectors of Machinery not elsewhere classified, are unambiguously characterised by a routinised regime according to both Malerba and Orsenigo (1997) and Breschi et al. (2000). Furthermore, based on case study evidence, some authors present also Machine tools (ISIC 2922) as an example of routinised technological regime (e.g. Malerba, 2001), although principal component analysis tends to classify it as entrepreneurial (Malerba and Orsenigo, 1997).
} 
EPL coefficients emerged in any specification of this sensitivity analysis, whose results are reported in the appendix (see Table A2). ${ }^{27}$

\section{Concluding Remarks}

The regression analysis we have presented, provides evidence that countries with a coordinated system of industrial relations tend to exhibit greater revealed technological comparative advantage in industries characterised by a routinised technological regime the more stringent the restrictions on hiring and firing. Furthermore, these countries tend to have greater comparative advantage in low-technology industries the lower the degree of employment protection. These results seem to reflect the fact that hiring and firing restrictions depress the incentive to innovate to a greater extent the slower the dynamics of demand and thus the greater the need of downsizing after having successfully innovated. These negative effects are however smaller the larger the scope for internal labour markets. In the context of a cumulative and specific knowledge base, stringent employment protection and coordinated systems of industrial relations, by aligning workers' and firms' objectives, enhancing the accumulation of firm-specific competencies and encouraging firm-sponsored training, may allow firms to fully exploit the potential of the internal labour market.

Nevertheless, although we can claim to have established empirically that coordinated countries have a greater comparative advantage in routinised industries the more stringent the employment protection legislation, this does not amount to say that employment protection has a beneficial effect in these industries and countries. Indeed, these results might mean that since the scope for internal labour reallocations is greater in routinised industries and encouraged in coordinated industrial relations regimes, firms are simply less sensitive to legislation hindering workforce adjustment on the external market. In other words, to fully assess the role of both product market regulation and labour market institutions within an absolute metric space, we need to go beyond the analysis of the patterns of technological comparative advantage discussed in the previous section. In an extension of this paper (Bassanini and Ernst, 2001) we discuss some regression results that allow a tentative assessment of the direction of the absolute effect of labour market policies and institutions on innovation. Labour market flexibility seems

\footnotetext{
${ }^{27}$ The significance of the derived coefficients concerning the overall effect of coordination is however sensitive to the classification of three industries (Computers, Precision and optical instruments and Motor vehicles).
} 
to be positively associated with $\mathrm{R} \& \mathrm{D}$ intensity in low-tech industries as well as in decentralised countries across all industries. Conversely, but consistent with the results presented in this paper, in countries with a coordinated industrial relations system, there is a negative association between labour market flexibility and R\&D intensity in industries with a more cumulative knowledge base. 
Table 1. Regression results: high-tech and low-tech industries

OLS with country and industry dummies

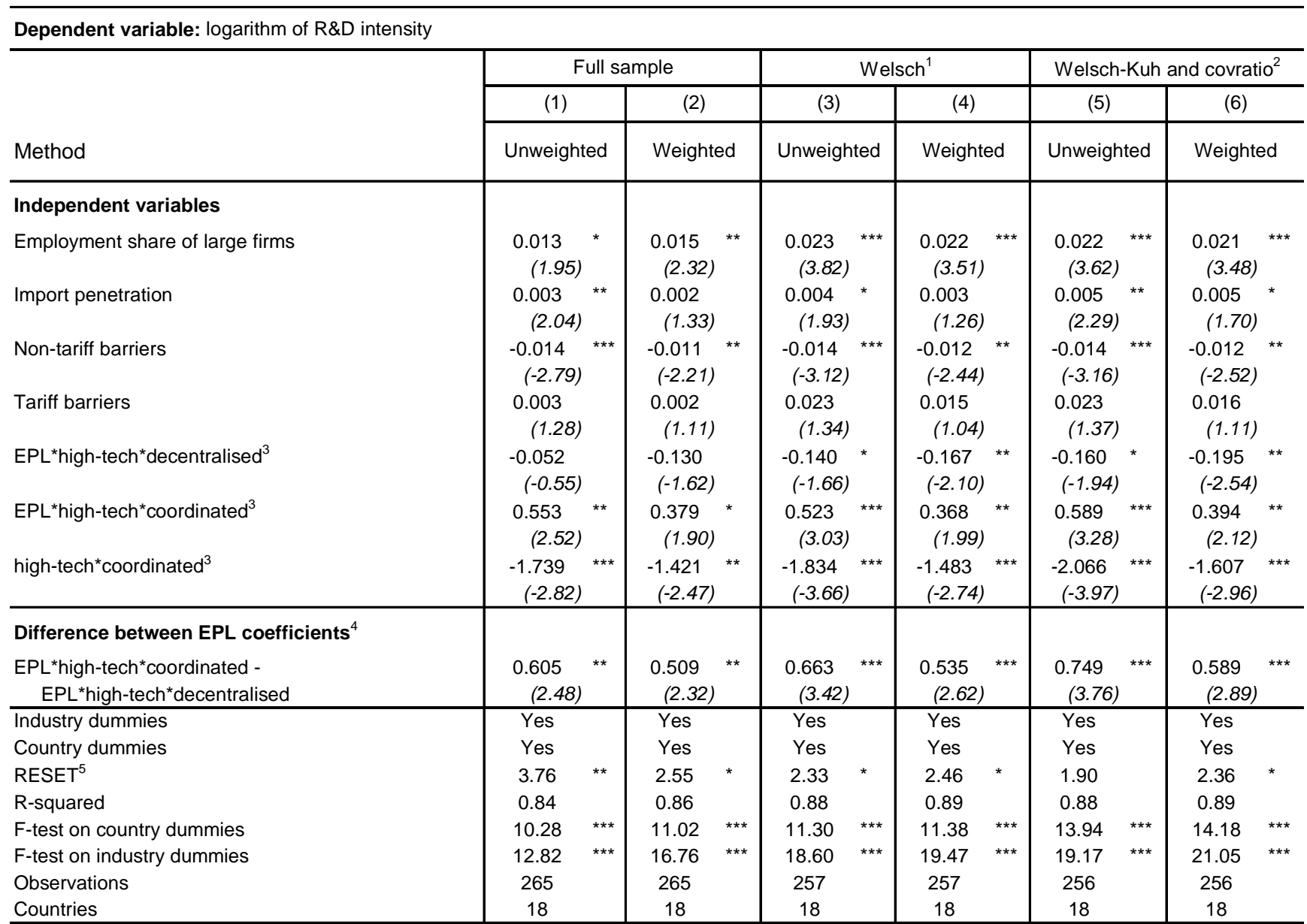

${ }^{1}$ Sample adjusted by excluding influential observations identified by the asymptotic Welsch distance cut-off.

2 Sample adjusted by excluding influential observations identified by the Welsch-Kuh distance (DFITS) cut-off combined with the covariance ratio cut-off.

3 "high-tech", "coordinated", and "decentralised", denote dummies for high-tech industries and types of industrial relation systems.

${ }^{4}$ Difference in the estimated coefficient of EPL in high-tech industries between coordinated and decentralised countries .

${ }^{5}$ Ramsey's omitted-variable test: F-test on the joint significance of the additional terms in a model augmented by including the second, third and fourth powers of the predicted values of the original model.

All equations include a constant. * ${ }^{* *},{ }^{* * *}$ denote significance at the $10 \%, 5 \%, 1 \%$ level, respectively. t-statistics adjusted for heteroskedasticity of unknown form in parentheses. 
Table 2. Regression results: technological regimes

OLS with country and industry dummies

\begin{tabular}{|c|c|c|c|c|c|c|c|c|c|c|c|}
\hline \multirow[b]{3}{*}{ Sample } & \multicolumn{5}{|c|}{ Unweighted } & \multicolumn{6}{|c|}{ Weighted with average employment } \\
\hline & \multicolumn{2}{|l|}{ (1) } & \multicolumn{2}{|l|}{ (2) } & (3) & \multicolumn{2}{|l|}{ (4) } & \multicolumn{2}{|l|}{ (5) } & \multicolumn{2}{|l|}{ (6) } \\
\hline & \multicolumn{2}{|c|}{$\begin{array}{c}\text { Full } \\
\text { sample }\end{array}$} & \multicolumn{2}{|l|}{ Welsch $^{1}$} & $\begin{array}{l}\text { Welsch-Kuh } \\
\text { and covratio }\end{array}$ & \multicolumn{2}{|l|}{$\begin{array}{c}\text { Full } \\
\text { sample }\end{array}$} & \multicolumn{2}{|c|}{ Welsch $^{1}$} & \multicolumn{2}{|c|}{$\begin{array}{l}\text { Welsch-Kuh } \\
\text { and covratio }\end{array}$} \\
\hline \multicolumn{12}{|l|}{ Independent variables } \\
\hline Employment share of large firms & $\begin{array}{l}0.013 \\
(1.88)\end{array}$ & & $\begin{array}{l}0.020 \\
(3.49)\end{array}$ & & $\begin{array}{l}0.019 \\
(3.37)\end{array}$ & $\begin{array}{c}0.015 \\
(2.34)\end{array}$ & ** & $\begin{array}{l}0.020 \\
(3.31)\end{array}$ & & $\begin{array}{c}0.019 \\
(3.30)\end{array}$ & )$^{\star \star \star \star}$ \\
\hline Import penetration & $\begin{array}{l}0.003 \\
(2.46)\end{array}$ & & $\begin{array}{l}0.004 \\
(1.73)\end{array}$ & & $\begin{array}{l}0.005 \\
(2.01)\end{array}$ & $\begin{array}{c}0.003 \\
(1.83)\end{array}$ & & $\begin{array}{l}0.003 \\
(1.06)\end{array}$ & & $\begin{array}{l}0.004 \\
(1.49)\end{array}$ & \\
\hline Non-tariff barriers & $\begin{array}{c}-0.014 \\
(-2.68)\end{array}$ & & $\begin{array}{l}-0.014 \\
(-2.95)\end{array}$ & & $\begin{array}{l}-0.014 \\
(-2.99)\end{array}$ & $\begin{array}{c}-0.011 \\
(-2.17)\end{array}$ & & $\begin{array}{c}-0.012 \\
(-2.40)\end{array}$ & & $\begin{array}{c}-0.012 \\
(-2.46)\end{array}$ & \\
\hline Tariff barriers & $\begin{array}{l}0.003 \\
(1.31)\end{array}$ & & $\begin{array}{l}0.025 \\
(1.47)\end{array}$ & & $\begin{array}{l}0.025 \\
(1.48)\end{array}$ & $\begin{array}{l}0.002 \\
(1.19)\end{array}$ & & $\begin{array}{l}0.017 \\
(1.14)\end{array}$ & & $\begin{array}{l}0.017 \\
(1.20)\end{array}$ & \\
\hline EPL $^{*}$ entrepreneurial ${ }^{*}$ decentralised ${ }^{3}$ & $\begin{array}{l}-0.070 \\
(-0.75)\end{array}$ & & $\begin{array}{c}-0.135 \\
(-1.51)\end{array}$ & & $\begin{array}{c}-0.154 \\
(-1.76)\end{array}$ * & $\begin{array}{c}-0.125 \\
(-1.60)\end{array}$ & & $\begin{array}{c}-0.141 \\
(-1.77)\end{array}$ & & $\begin{array}{c}-0.171 \\
(-2.23)\end{array}$ & \\
\hline EPL $^{*}$ entrepreneurial ${ }^{*}$ coordinated ${ }^{3}$ & $\begin{array}{l}0.273 \\
(1.58)\end{array}$ & & $\begin{array}{l}0.231 \\
(1.46)\end{array}$ & & $\begin{array}{l}0.233 \\
(1.47)\end{array}$ & $\begin{array}{l}0.208 \\
(1.14)\end{array}$ & & $\begin{array}{l}0.153 \\
(0.88)\end{array}$ & & $\begin{array}{l}0.165 \\
(0.94)\end{array}$ & \\
\hline entrepreneurial $^{*}$ coordinated ${ }^{3}$ & $\begin{array}{c}-1.060 \\
(-1.96)\end{array}$ & * & $\begin{array}{c}-1.177 \\
(-2.48)\end{array}$ & & $\begin{array}{l}-1.218 \text { ** } \\
(-2.57)\end{array}$ & $\begin{array}{c}-0.984 \\
(-1.76)\end{array}$ & & $\begin{array}{c}-0.927 \\
(-1.75)\end{array}$ & & $\begin{array}{c}-1.011 \\
(-1.91)\end{array}$ & \\
\hline EPL $^{*}$ routinised ${ }^{*}$ decentralised ${ }^{3}$ & $\begin{array}{c}-0.033 \\
(-0.25)\end{array}$ & & $\begin{array}{c}-0.123 \\
(-1.10)\end{array}$ & & $\begin{array}{c}-0.140 \\
(-1.28)\end{array}$ & $\begin{array}{l}-0.147 \\
(-1.19)\end{array}$ & & $\begin{array}{c}-0.184 \\
(-1.66)\end{array}$ & & $\begin{array}{c}-0.208 \\
(-1.92)\end{array}$ & \\
\hline EPL $^{*}$ routinised ${ }^{*}$ coordinated ${ }^{3}$ & $\begin{array}{l}0.948 \\
(2.79)\end{array}$ & ** & $\begin{array}{l}1.069 \\
(4.84)\end{array}$ & & $\begin{array}{l}1.144 \\
(5.90)\end{array}$ & $\begin{array}{c}0.897 \\
(2.46)\end{array}$ & & $\begin{array}{c}1.101 \\
(4.72)\end{array}$ & *** & $\begin{array}{c}1.135 \\
(5.19)\end{array}$ & )$^{\star \star *}$ \\
\hline routinised $^{*}$ coordinated $^{3}$ & $\begin{array}{c}-2.727 \\
(-3.02)\end{array}$ & ** & $\begin{array}{c}-3.106 \\
(-4.51)\end{array}$ & $* * *$ & $\begin{array}{l}-3.358 \quad \text { *** } \\
(-5.41)\end{array}$ & $\begin{array}{c}-2.797 \\
(-2.89)\end{array}$ & $* * \star$ & $\begin{array}{c}-3.367 \\
(-4.72)\end{array}$ & *** & $\begin{array}{c}-3.499 \\
(-5.19)\end{array}$ & *** \\
\hline Industry dummies & Yes & & Yes & & Yes & Yes & & Yes & & Yes & \\
\hline Country dummies & Yes & & Yes & & Yes & Yes & & Yes & & Yes & \\
\hline RESET $^{4}$ & 3.67 & ** & 2.32 & * & 2.09 & 2.36 & * & 2.58 & * & 2.58 & * \\
\hline R-squared & 0.84 & & 0.89 & & 0.89 & 0.86 & & 0.89 & & 0.90 & \\
\hline F-test on country dummies & 10.84 & *** & 11.81 & *** & 14.79 & 11.47 & *** & 12.07 & *** & 15.11 & *** \\
\hline F-test on industry dummies & 13.81 & $\star * *$ & 19.53 & $\star \star \star \star$ & 20.19 & 16.89 & $\star \star \star *$ & 20.75 & *** & 22.00 & 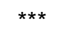 \\
\hline Observations & 265 & & 257 & & 256 & 265 & & 257 & & 256 & \\
\hline Countries & 18 & & 18 & & 18 & 18 & & 18 & & 18 & \\
\hline
\end{tabular}

${ }^{1}$ Sample adjusted by excluding influential observations identified by the asymptotic Welsch distance cut-off.

${ }^{2}$ Sample adjusted by excluding influential observations identified by the Welsch-Kuh distance (DFITS) cut-off combined with the covariance ratio cut-off.

3 "routinised", "entrepreneurial", "coordinated", and "decentralised", denote dummies for technological regimes and types of industrial relation systems.

${ }^{4}$ Ramsey's omitted-variable test: F-test on the joint significance of the additional terms in a model augmented by including the second, third and fourth powers of the predicted values of the original model.

All equations include a constant. * ${ }^{\star \star \star},{ }^{\star \star \star}$ denote significance at the $10 \%, 5 \%, 1 \%$ level, respectively. t-statistics adjusted for heteroskedasticity of unknown form in parentheses. 
Table 3. Estimated differences in the impact of EPL between industrial relations systems and between technological regimes OLS with country and industry dummies ${ }^{1}$

\begin{tabular}{|c|c|c|c|c|c|c|}
\hline \multicolumn{7}{|l|}{ Dependent variable: logarithm of $R \& D$ intensity } \\
\hline & \multicolumn{3}{|c|}{ Unweighted } & \multicolumn{3}{|c|}{ Weighted with average employment } \\
\hline & (1) & $(2)$ & (3) & (4) & (5) & (6) \\
\hline Sample & $\begin{array}{l}\text { Full } \\
\text { sample }\end{array}$ & Welsch $^{2}$ & $\begin{array}{l}\text { Welsch-Kuh } \\
\text { and covratio }\end{array}$ & $\begin{array}{l}\text { Full } \\
\text { sample }\end{array}$ & Welsch $^{2}$ & $\begin{array}{l}\text { Welsch-Kuh } \\
\text { and covratio }\end{array}$ \\
\hline \multicolumn{7}{|l|}{ Differences between EPL coefficients ${ }^{4}$} \\
\hline $\begin{array}{l}\text { EPL*routinised }{ }^{*} \text { coordinated - } \\
\text { EPL }^{*} \text { entrepreneurial }{ }^{*} \text { coordinated }\end{array}$ & $\begin{array}{l}0.6755^{* *} \\
(2.21)\end{array}$ & $\begin{array}{l}0.8388^{* * *} \\
(3.84)\end{array}$ & $\begin{array}{l}0.9111^{* * *} \\
(4.90)\end{array}$ & $\begin{array}{l}0.6899^{* *} \\
(1.99)\end{array}$ & $\begin{array}{l}0.9488^{* * *} \\
(4.23)\end{array}$ & $\begin{array}{l}0.9700^{* * *} \\
(4.66)\end{array}$ \\
\hline $\begin{array}{l}\text { EPL**outinised }{ }^{*} \text { decentralised - } \\
\qquad \mathrm{EPL}^{*} \text { entrepreneurial }{ }^{*} \text { decentralised }\end{array}$ & $\begin{array}{l}0.037 \\
(0.32)\end{array}$ & $\begin{array}{l}0.012 \\
\quad(0.10)\end{array}$ & $\begin{array}{l}0.014 \\
(0.14)\end{array}$ & $\begin{array}{l}-0.021 \\
(-0.20)\end{array}$ & $\begin{array}{l}-0.043 \\
(-0.42)\end{array}$ & $\begin{array}{l}-0.037 \\
(-0.36)\end{array}$ \\
\hline $\begin{array}{l}\text { EPL*routinised*coordinated - } \\
\text { EPL*'routinised*decentralised }\end{array}$ & $\begin{array}{l}0.981 \\
(2.61)\end{array}$ & $\begin{array}{l}1.1922^{* * *} \\
(4.82)\end{array}$ & $\begin{array}{l}1.285^{* * *} \\
(5.74)^{*}\end{array}$ & $\begin{array}{l}1.044^{* * *} \\
(2.63)\end{array}$ & $\begin{array}{l}1.286 \\
(4.98)\end{array}$ & $\begin{array}{l}1.342^{* * *} \\
(5.50)\end{array}$ \\
\hline $\begin{array}{l}\text { (EPL }{ }^{*} \text { routinised }{ }^{*} \text { coor.-EPL*entrepren. }{ }^{*} \text { coor.) - } \\
\left.\text { (EPL*routinised }{ }^{*} \text { decentr.-EPL*entrepren. }{ }^{*} \text { decentr. }\right)\end{array}$ & $\begin{array}{c}0.638 * \\
(1.91)\end{array}$ & $\begin{array}{l}0.8266^{* * *} \\
(3.37)\end{array}$ & $\begin{array}{l}0.8977^{* * *} \\
(4.14)\end{array}$ & $\begin{array}{c}0.711{ }^{*}(1.93) \\
\end{array}$ & $\begin{array}{l}0.991 \\
(4.01)\end{array}$ & $\begin{array}{l}1.0066^{* * *} \\
(4.34)\end{array}$ \\
\hline
\end{tabular}

${ }^{1}$ The table reports only estimated differences between coefficients. See Table 2 for the specification, diagnostic statistics and complete results.

${ }^{2}$ Sample adjusted by excluding influential observations identified by the asymptotic Welsch distance cut-off.

${ }^{3}$ Sample adjusted by excluding influential observations identified by the Welsch-Kuh distance (DFITS) cut-off combined with the covariance ratio cut-off.

${ }^{4}$ Differences between estimated coefficients of EPL variables.

${ }^{*},{ }^{* *},{ }^{* * *}$ denote significance at the $10 \%, 5 \%, 1 \%$ level, respectively. t-statistics adjusted for heteroskedasticity of unknown form in parentheses.

Table 4. Derived impact of coordination on revealed comparative advantage

OLS with country and industry dummies ${ }^{1}$

Dependent variable: logarithm of R\&D intensity

\begin{tabular}{|c|c|c|c|c|c|c|}
\hline \multirow[b]{3}{*}{ Sample } & \multicolumn{3}{|c|}{ Unweighted } & \multicolumn{3}{|c|}{ Weighted with average employment } \\
\hline & (1) & $(2)$ & (3) & (4) & (5) & (6) \\
\hline & $\begin{array}{c}\text { Full } \\
\text { sample }\end{array}$ & Welsch $^{2}$ & $\begin{array}{l}\text { Welsch-Kuh } \\
\text { and covratio } \\
\end{array}$ & $\begin{array}{c}\text { Full } \\
\text { sample }\end{array}$ & Welsch $^{2}$ & $\begin{array}{l}\text { Welsch-Kuh } \\
\text { and covratio }\end{array}$ \\
\hline \multicolumn{7}{|c|}{ Derived estimated effect of coordination ${ }^{4}$} \\
\hline $\begin{array}{l}\text { At the median level of EPL: } \\
\text { entrepreneurial industries }\end{array}$ & $\begin{array}{c}-0.233 \\
(-1.17)\end{array}$ & $\begin{array}{l}-0.296 * \\
(-1.70)\end{array}$ & $\begin{array}{l}-0.284 * \\
(-1.65)\end{array}$ & $\begin{array}{l}-0.182 \\
(-0.94)\end{array}$ & $\begin{array}{l}-0.216 \\
(-1.21)\end{array}$ & $\begin{array}{l}-0.201 \\
(-1.15)\end{array}$ \\
\hline routinised industries & $\begin{array}{c}-0.364 \\
(-1.39)\end{array}$ & $\begin{array}{c}-0.233 \\
(-1.02)\end{array}$ & $\begin{array}{c}-0.262 \\
(-1.19)\end{array}$ & $\begin{array}{c}-0.282 \\
(-1.04)\end{array}$ & $\begin{array}{c}-0.268 \\
(-1.13)\end{array}$ & $\begin{array}{c}-0.263 \\
(-1.15)\end{array}$ \\
\hline $\begin{array}{l}\text { At the third quartile of EPL: } \\
\text { entrepreneurial industries }\end{array}$ & $\begin{array}{l}-0.003 \\
(-0.01)\end{array}$ & $\begin{array}{l}-0.051 \\
(-0.24)\end{array}$ & $\begin{array}{l}-0.024 \\
(-0.12)\end{array}$ & $\begin{array}{l}0.041 \\
(0.20)\end{array}$ & $\begin{array}{l}-0.019 \\
(-0.09)\end{array}$ & $\begin{array}{l}0.024 \\
(0.12)\end{array}$ \\
\hline routinised industries & $\begin{array}{l}0.293 \\
(0.75)\end{array}$ & $\begin{array}{l}0.5655^{* *} \\
(2.28)\end{array}$ & $\begin{array}{l}0.598 \text { ** } \\
(2.49)\end{array}$ & $\begin{array}{l}0.417 \\
(1.05)\end{array}$ & $\begin{array}{l}0.593 * * \\
(2.26)\end{array}$ & $\begin{array}{l}0.636{ }^{* *} \\
(2.52)\end{array}$ \\
\hline
\end{tabular}

${ }^{1}$ The table reports only derived coefficients. See Table 2 for the specification, diagnostic statistics and complete results.

${ }^{2}$ Sample adjusted by excluding influential observations identified by the asymptotic Welsch distance cut-off.

${ }^{3}$ Sample adjusted by excluding influential observations identified by the Welsch-Kuh distance (DFITS) cut-off combined with the covariance ratio cut-off.

${ }^{4}$ The coefficient of the overall effect of coordination for a given industry type is obtained as the sum of the estimated coefficient of the dummy for that

industry type in coordinated countries and the difference in the estimated coefficients of EPL for that industry type between coordinated and

decentralised countries multiplied by a chosen value of EPL.

${ }^{*},{ }^{* *},{ }^{* * *}$ denote significance at the $10 \%, 5 \%, 1 \%$ level, respectively. t-statistics adjusted for heteroskedasticity of unknown form in parentheses. 
Table 5. Sensitivity analysis: including additional PMR controls Unweighted OLS with country and industry dummies ${ }^{1}$

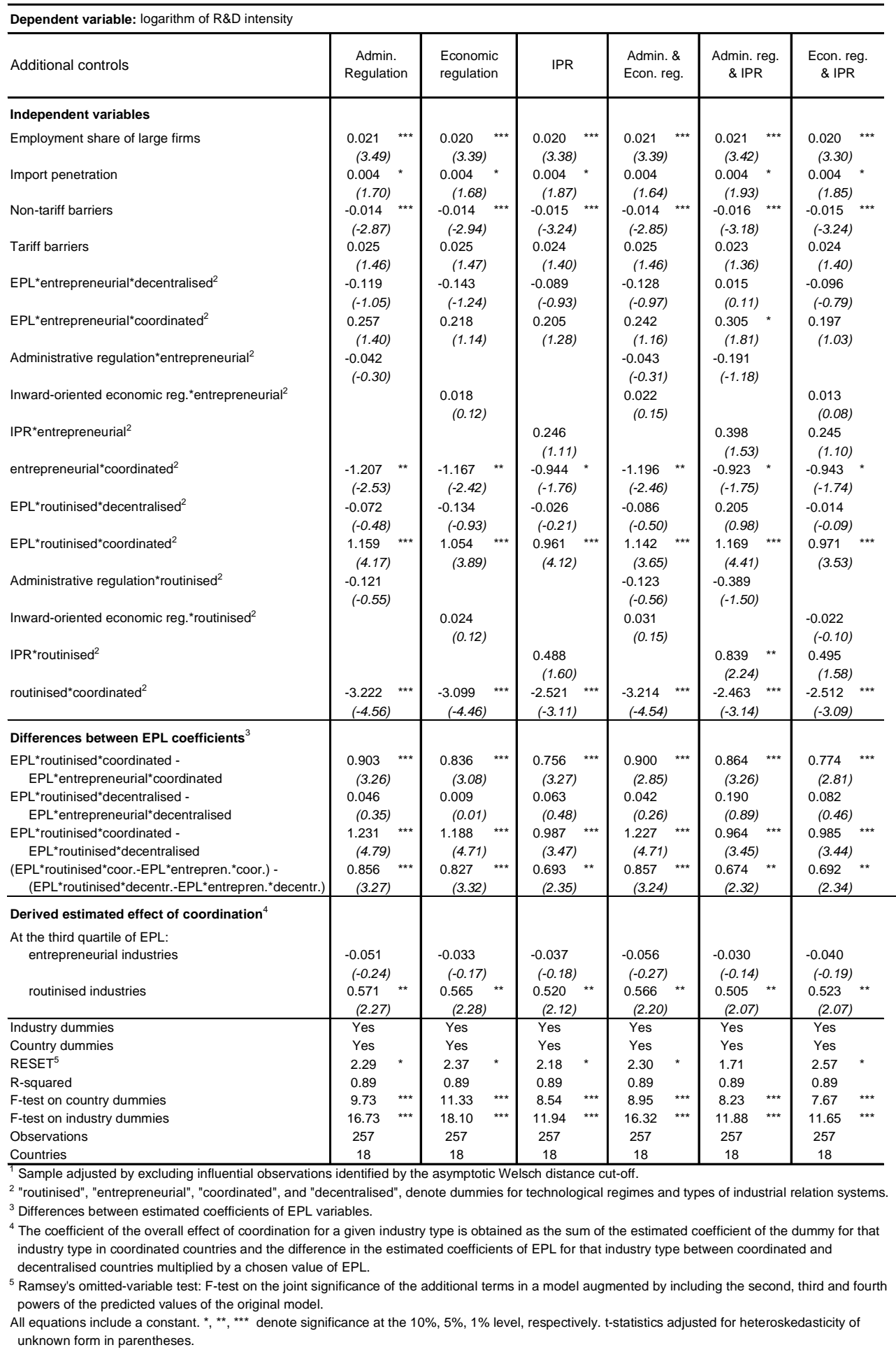


Figure 1. Patents per million of inhabitants and employment protection (1) Panel A: Countries with low and intermediate levels of coordination

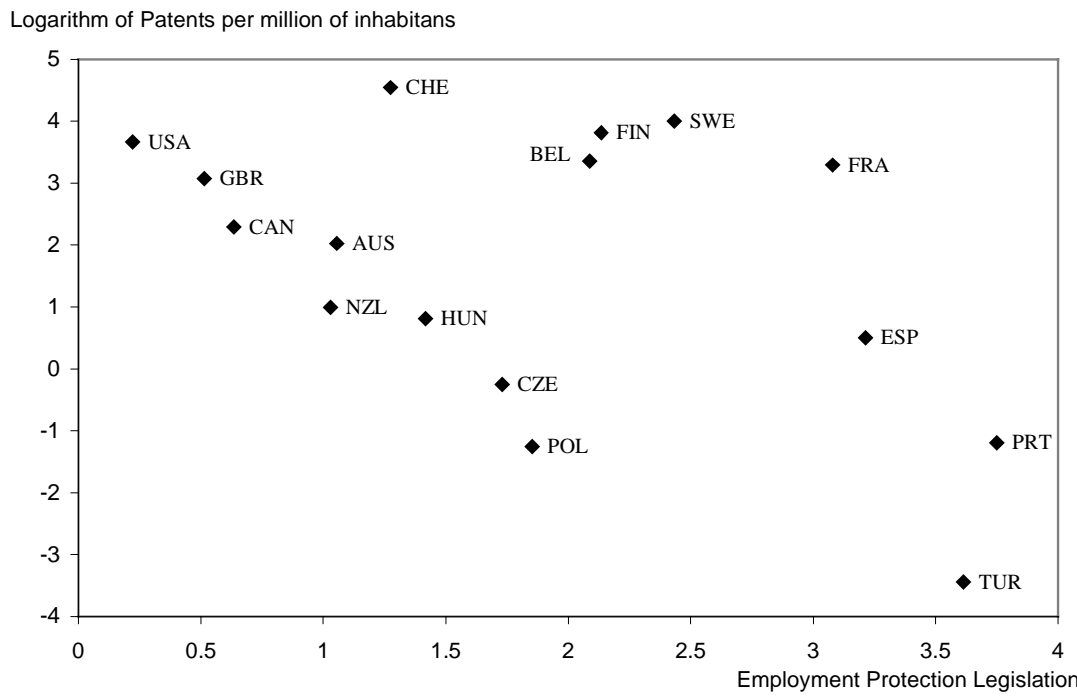

Panel B: Coordinated countries

Logarithm of Patents per million of inhabitans

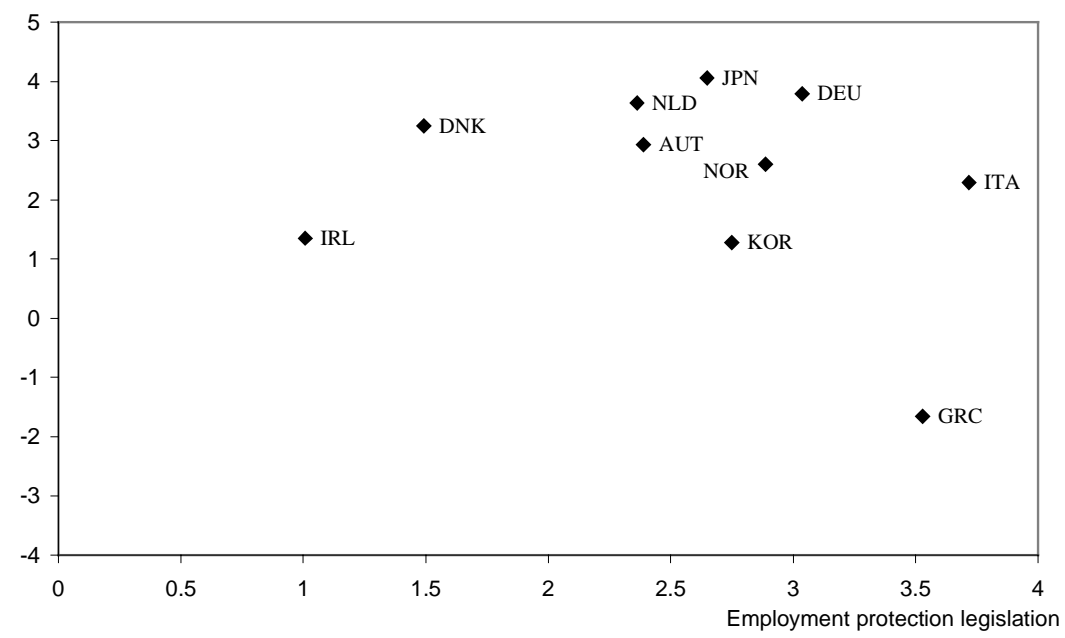

1. The OECD summary index of employment protection legislation is from Nicoletti et al. (1999). Patents are defined as consolidated family of patent at EPO, USPTO and JPO by country of invention and priority year 1993. The level of coordination is derived from the OECD index of coordination of the wage bargain (Elmeskov et al. , 1998, and OECD Economic Surveys, various countries and years).

Source: OECD. 
Figure 2. Sensitivity to variation of country coverage (1)

Panel A :

Tests of absence of effect of EPL on the comparative advantage of coordinated countries in routinised industries

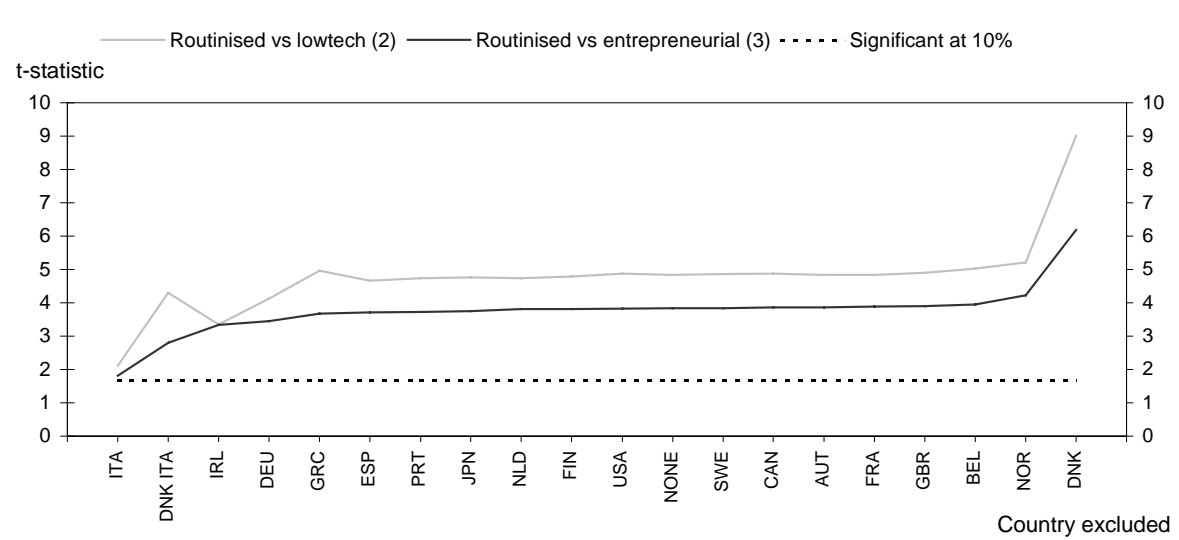

Panel B :

Tests of absence of structural differences in the effect of EPL on the comparative advantage between different country groups

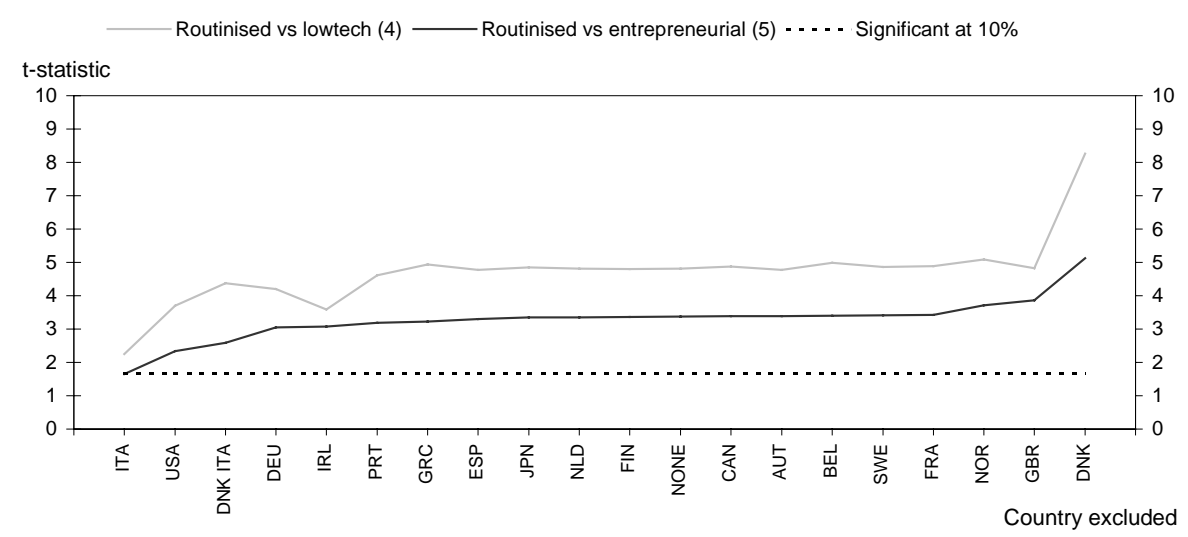

1.The figure shows t-statistics corresponding to different tests of hypotheses obtained by re-estimating the preferred specification (cf. Table 2, column 2) after excluding one country at a time from the sample. NONE identifies test statistics of the preferred specification for the purpose of comparison.

2. t-statistic of the coefficient of the interaction variable $E P L^{*}$ routinised ${ }^{*}$ coordinated.

3. t-statistic of the difference between the coefficients of $E P L^{*}$ routinised ${ }^{*}$ coordinated and $E P L^{*}$ entrepreneurial ${ }^{*}$ coordinated.

4. test statistic of the hypothesis that the coefficient of $E P L^{*}$ routinised ${ }^{*}$ coordinated is equal to the coefficient of $E P L^{*}$ routinised*decentralised (t-statistic).

5. test statistic of the hypothesis that the difference between the coefficients of $E P L^{*}$ routinised ${ }^{*}$ coordinated and $E P L^{*}$ entrepreneurial ${ }^{*}$ coordinated is equal to the difference between the coefficients of $E P L^{*}$ routinised ${ }^{*}$ decentralised and $E P L^{*}$ entrepreneurial*decentralised (t-statistic). 


\section{APPENDIX}

Table A1. Descriptive statistics

\begin{tabular}{|c|c|c|c|}
\hline Variable & Measurement unit & Mean & $\begin{array}{l}\text { Standard } \\
\text { Deviation }\end{array}$ \\
\hline R\&D (BERD) intensity & percentage of total output & 2.43 & 3.39 \\
\hline Import penetration & percentage of apparent demand & 50.50 & 52.01 \\
\hline Employment share of large firms & percentage & 78.38 & 15.01 \\
\hline Tariff barriers & percentage & 6.05 & 10.04 \\
\hline Non-tariff barriers & percentage & 5.58 & 16.62 \\
\hline EPL & $0-6$ index & 2.35 & 1.04 \\
\hline coordinated $^{1}$ & dummy & 0.47 & 0.50 \\
\hline decentralised $^{1}$ & dummy & 0.53 & 0.50 \\
\hline high-tech ${ }^{1}$ & dummy & 0.46 & 0.50 \\
\hline low-tech ${ }^{1}$ & dummy & 0.54 & 0.50 \\
\hline entrepreneurial $^{1}$ & dummy & 0.24 & 0.43 \\
\hline routinised $^{1}$ & dummy & 0.22 & 0.42 \\
\hline IPR & $0-5$ index & 3.84 & 0.46 \\
\hline Administrative regulation & $0-6$ index & 2.00 & 0.77 \\
\hline Inward-oriented Economic reg. & $0-6$ index & 1.94 & 0.77 \\
\hline Employment share of foreign affiliates & percentage & 26.00 & 23.76 \\
\hline Government-financed BERD & percentage of total BERD & 8.95 & 11.00 \\
\hline
\end{tabular}

1 "high-tech", "low-tech", "routinised", "entrepreneurial", "coordinated", and "decentralised", denote dummies for types of industries and industrial relations systems. 
Table A2. Sensitivity analysis: Varying the classification of industries

Unweighted OLS with country and industry dummies

\begin{tabular}{|c|c|c|c|c|c|c|c|c|c|}
\hline \multicolumn{10}{|l|}{ Dependent variable: logarithm of R\&D intensity } \\
\hline Industries classified as routinised (ISIC codes) & $\begin{array}{l}24,30,32 \\
34,35\end{array}$ & $\begin{array}{l}29,30,32 \\
34,35\end{array}$ & $\begin{array}{l}30,31,32 \\
\quad 34,35\end{array}$ & $\begin{array}{l}30,32,33 \\
\quad 34,35\end{array}$ & $30,32,34$ & $30,32,35$ & $30,34,35$ & $32,34,35$ & 34,35 \\
\hline \multicolumn{10}{|l|}{ Selected EPL coefficients ${ }^{1}$} \\
\hline \multicolumn{10}{|l|}{ Full Sample } \\
\hline EPL'routinised ${ }^{\star}$ coordinated & $\begin{array}{l}0.7499^{\star \star \star} \\
(2.60)\end{array}$ & $\begin{array}{l}0.7499^{\star \star \star} \\
(2.61)\end{array}$ & $\begin{array}{l}0.810{ }^{\star \star \star \star} \\
(2.68)\end{array}$ & $\begin{array}{l}0.794^{* * *} \\
(2.61)^{*}\end{array}$ & $\begin{array}{l}1.0955^{* \star *} \\
(4.30)\end{array}$ & $\begin{array}{c}0.905{ }^{* *} \\
(2.46)\end{array}$ & $\begin{array}{l}0.944{ }^{* \star} \\
(2.44)\end{array}$ & $\begin{array}{l}0.876{ }^{* \star} \\
(2.13)\end{array}$ & $\begin{array}{c}0.8666^{*} \\
(1.70)\end{array}$ \\
\hline $\begin{array}{l}\text { EPL*routinised*coordinated - } \\
\text { EPL"entrepreneurial* } \\
\text { coordinated }\end{array}$ & $\begin{array}{c}0.464 * \\
(1.84)\end{array}$ & $\begin{array}{c}0.469 * \\
(1.82)\end{array}$ & $\begin{array}{l}0.5633^{\star *} \\
(1.97)\end{array}$ & $\begin{array}{c}0.528 * \\
(1.83)\end{array}$ & $\begin{array}{l}0.736 \quad * \star * \\
(2.81)\end{array}$ & $\begin{array}{c}0.558 * \\
(1.66)\end{array}$ & $\begin{array}{c}0.591 * \\
(1.65)\end{array}$ & $\begin{array}{l}0.445 \\
(1.16)\end{array}$ & $\begin{array}{l}0.388 \\
(0.79)\end{array}$ \\
\hline $\begin{array}{l}\text { EPL*routinised*coordinated - } \\
\text { EPL"routinised*decentralised }\end{array}$ & & $\begin{array}{l}0.783 * * \\
(2.48)\end{array}$ & $\begin{array}{l}0.885 * * * \\
(2.65)\end{array}$ & $\begin{array}{c}0.792 * * \\
(2.35)\end{array}$ & $\begin{array}{l}1.138 * * * \\
(3.90)\end{array}$ & $\begin{array}{c}0.852 * * \\
(2.08)\end{array}$ & $\begin{array}{l}1.012 \text { ** } \\
(2.40)\end{array}$ & $\begin{array}{l}0.953 * \star \\
(2.16)\end{array}$ & $\begin{array}{c}1.012 \\
(1.90)\end{array}$ \\
\hline 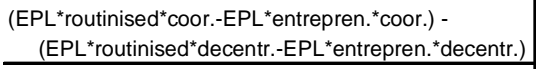 & $\begin{array}{c}0.4922^{*} \\
(1.79)\end{array}$ & $\begin{array}{l}0.432 \\
(1.54)\end{array}$ & $\begin{array}{l}0.616 * * \\
(1.98)\end{array}$ & $\begin{array}{l}0.377 \\
(1.21) \\
\end{array}$ & $\begin{array}{l}0.713 * * \\
(2.47)\end{array}$ & $\begin{array}{l}0.394 \\
(1.07)\end{array}$ & $\begin{array}{l}0.629 \\
(1.62) \\
\end{array}$ & $\begin{array}{l}0.475 \\
(1.18) \\
\end{array}$ & $\begin{array}{l}0.521 \\
(1.03)\end{array}$ \\
\hline \multicolumn{10}{|l|}{ Adjusted sample (Welsch distance cut-off) ${ }^{2}$} \\
\hline EPL'routinised*coordinated & $\begin{array}{l}0.7399^{* * *} \\
(3.10)\end{array}$ & $\begin{array}{l}0.739^{* * *} \\
(3.29)^{*}\end{array}$ & $\begin{array}{l}0.8722^{* * \star} \\
(4.24)\end{array}$ & $\begin{array}{l}0.8455^{\star \star \star \star} \\
(3.89)\end{array}$ & $\begin{array}{l}0.7711^{* * *} \\
(3.31)^{*}\end{array}$ & $\begin{array}{l}1.0688^{* \star \star} \\
(4.48)\end{array}$ & $\begin{array}{l}1.1055^{\star \star \star} \\
(4.55)^{*}\end{array}$ & $\begin{array}{l}1.1588^{\star \star \star \star} \\
(5.21)^{*}\end{array}$ & $\begin{array}{l}1.2666^{* \star \star} \\
(6.84)^{*}\end{array}$ \\
\hline 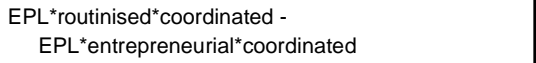 & $\begin{array}{l}0.4677^{\star \star} \\
(2.04)\end{array}$ & $\begin{array}{l}0.4733^{* *} \\
(1.97)\end{array}$ & $\begin{array}{l}0.6811^{* * *} \\
(3.12)\end{array}$ & $\begin{array}{l}0.633^{* * *} \\
(2.87)^{*}\end{array}$ & $\begin{array}{l}0.341 \\
(1.35)\end{array}$ & $\begin{array}{l}0.775^{\star \star * *} \\
(3.29)\end{array}$ & $\begin{array}{l}0.7966^{* * *} \\
(3.19)\end{array}$ & $\begin{array}{l}0.873^{* * *} \\
(3.83)^{*}\end{array}$ & $\begin{array}{l}0.9233^{* \star \star} \\
(4.82)\end{array}$ \\
\hline $\begin{array}{l}\text { EPL*routinised*coordinated - } \\
\text { EPL"routinised*decentralised }\end{array}$ & $\begin{array}{l}0.892^{* * \star} \\
(3.52)\end{array}$ & $\begin{array}{l}0.859^{* * *} \\
(3.48)\end{array}$ & $\begin{array}{l}1.043^{* * *} \\
(4.56)\end{array}$ & $\begin{array}{l}0.9311^{* * \star} \\
(3.84)\end{array}$ & $\begin{array}{l}0.913 * * * \\
(3.49)\end{array}$ & $\begin{array}{c}1.1033^{* * \star} \\
(4.06)\end{array}$ & $\begin{array}{l}1.2799^{* \star *} \\
(4.64)\end{array}$ & $\begin{array}{l}1.324 \\
(5.39)\end{array}$ & $\begin{array}{l}1.511)^{* * *} \\
(6.90)\end{array}$ \\
\hline 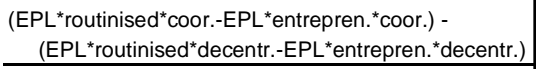 & $\begin{array}{l}0.515 * * \\
(2.06)\end{array}$ & $\begin{array}{c}0.450 * \\
(1.70)\end{array}$ & $\begin{array}{l}0.763 * \star * * \\
(3.18)\end{array}$ & $\begin{array}{l}0.496 \star * \\
(2.04)\end{array}$ & $\begin{array}{l}0.349 \\
(1.26)\end{array}$ & $\begin{array}{c}0.622 * * \\
(2.33)\end{array}$ & $\begin{array}{l}0.860^{\star \star \star *} \\
(3.07)^{*}\end{array}$ & $\begin{array}{l}0.930^{*} \star * \star \\
(3.70)\end{array}$ & $\begin{array}{c}1.077^{\star \star * \star} \\
(4.84)^{*}\end{array}$ \\
\hline \multicolumn{10}{|l|}{$\begin{array}{l}\text { Adjusted sample (Welsch-Kuh distance and } \\
\text { covratio cut-offs) }\end{array}$} \\
\hline EPLroutinised ${ }^{*}$ coordinated & $\begin{array}{l}0.8355^{\star \star \star \star} \\
(3.62)\end{array}$ & $\begin{array}{l}0.8333^{* \star *} \\
(3.79)\end{array}$ & $\begin{array}{l}0.9611^{* * *} \\
(4.86)\end{array}$ & $\begin{array}{l}0.926{ }^{* * *} \\
(4.39)\end{array}$ & $\begin{array}{c}1.0222^{\star \star * \star} \\
(4.21)^{\star 2}\end{array}$ & $\begin{array}{l}1.146{ }^{* \star *} \\
(5.56)^{*}\end{array}$ & $\begin{array}{l}1.1944^{* \star \star} \\
(5.88)\end{array}$ & $\begin{array}{l}1.170^{\star \star * *} \\
(5.35)^{*}\end{array}$ & $\begin{array}{l}1.266^{* \star *} \\
(6.67)^{*}\end{array}$ \\
\hline $\begin{array}{l}\text { EPL*routinised*coordinated - } \\
\text { EPL"entrepreneurial*coordinated }\end{array}$ & $\begin{array}{l}0.5666^{* * *} \\
(2.63)\end{array}$ & $\begin{array}{c}0.5677^{* *} \\
(2.47)\end{array}$ & $\begin{array}{l}0.770 \quad * \star * \\
(3.76)\end{array}$ & $\begin{array}{l}0.7111^{* * \star} \\
(3.38)\end{array}$ & $\begin{array}{l}0.595 \text { ** } \\
(2.29)\end{array}$ & $\begin{array}{c}0.8488^{\star \star \star} \\
(4.26)\end{array}$ & $\begin{array}{l}0.880^{\star \star \star \star} \\
(4.28)\end{array}$ & $\begin{array}{l}0.7811^{* \star \star} \\
(3.36)\end{array}$ & $\begin{array}{l}0.8277^{* * *} \\
(4.00)\end{array}$ \\
\hline EPL*routinised*coordinated - & $\begin{array}{l}1.004^{* * *} \\
(4.07)\end{array}$ & $\begin{array}{l}0.973^{* * *} \\
(4.03)\end{array}$ & $1.149 * * *$ & $\begin{array}{l}1.032^{* * *} \\
(4.39)\end{array}$ & $1.179^{* * *}$ & $1.200^{* * *}$ & 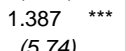 & $1.348^{* * *}$ & 1.527 * \\
\hline $\begin{array}{l}\text { EPL*routinised*decentralised } \\
\text { (EPL'routinised*coor.-EPL"entrepren." }{ }^{*} \text { coor.) - }\end{array}$ & 0.608 ** & $0.547 * *$ & $0.849^{(5.1)} * * *$ & $0.576 * *$ & $0.601 * *$ & $0.696 * \star(4.96)$ & $0.946 * \star 6^{(5.4 *}$ & $0.826 * \star{ }^{(5.58)}$ & $0.975^{* * *}$ \\
\hline (EPL"routinised decentr.-EPL*entrepren. ${ }^{*}$ decentr.) & $(2.56)$ & $(2.15)$ & (3.72) & $(2.46)$ & $(2.11)$ & $(2.97)$ & (3.90) & (3.22) & $(4.14)$ \\
\hline
\end{tabular}

(EPL"routinised*decentr.-EPL*entrepren. ${ }^{*}$ decentr.

industrial relation systems.

Sample adjusted by excluding influential observations identified by the asymptotic Welsch distance cut-off.

Sample adjusted by excluding influential observations identified by the Welsch-Kuh distance (DFITS) cut-off combined with the covariance ratio cut-off.

Specifications identical to Table 2, except for the classification of industries. ${ }^{*},{ }^{* *},{ }^{* * *}$ denote significance at the $10 \%, 5 \%, 1 \%$ level, respectively. $t$-statistics adjusted for heteroskedasticity of unknown form in parentheses. 


\section{REFERENCES}

ACEMOGLU, D. (1997a), "Training and Innovation in an Imperfect Labour Market", Review of Economic Studies, Vol. 64, pp. 445-464.

ACEMOGLU, D. (1997b), "Technology, Unemployment and Efficiency", European Economic Review, Vol. 41, pp. 525-533.

ACEMOGLU, D. and J.S. PISCHKE (1998), "Why Do Firms Train? Theory and Evidence", Quarterly Journal of Economics, Vol. 113, pp. 79-119.

ACEMOGLU, D. and J.S. PISCHKE (1999a), "Beyond Becker: Training in Imperfect Labor Markets", Economic Journal, Vol. 109, pp. F112-142.

ACEMOGLU, D. and J.S. PISCHKE (1999b), "The Structure of Wages and Investment in General Training", Journal of Political Economy, Vol. 107, pp. 539-572.

AGELL, J. (1999), "On the Benefits from Rigid Labour Markets: Norms, Market Failures, and Social Insurance," Economic Journal, Vol. 109, pp. F143-F164.

AGHION, P., N. BLOOM, R. BLUNDELL, R. GRIFFITH and P. HOWITT (2001b), "Empirical Estimates of Product Market Competition and Innovation", University College London, mimeo.

AGHION, P., C. HARRIS, P. HOWITT and J. VICKERS (2001a), "Competition, Imitation and Growth with Step-by-Step Innovation", Review of Economic Studies, Vol. 68, pp.467-492.

AUDRETSCH, D. (1995), Innovation and Industry Evolution, Cambridge: Mass.: The MIT Press.

BASSANINI, A., and E. ERNST (2002), "Labour Market Institutions, Product Market Regulation, and Innovation: Cross-country Evidence", OECD Economics Department Working Paper, forthcoming.

BECKER, G. (1964), Human Capital, Chicago: The University of Chicago Press.

BLAU, F., and L. KAHN (1996), "International Differences in Male Wage Inequality: Institutions vs. Market Forces", Journal of Political Economy, Vol. 104, pp. 791837.

BLINDER, A. and A. KRUEGER (1996), "Labor Turnover in the USA and Japan: A Tale of Two Countries", Pacific Economic Review, Vol. 1, pp. 27-57.

BOONE, J. (2000), "Competitive Pressure: The Effects on Investments in Product and Process Innovation", RAND Journal of Economics, Vol. 31, No. 3, pp. 549-569.

BOYER, R. (1988), "Technical Change and the Theory of Regulation", in G. Dosi, C. Freeman, R. Nelson, G. Silverberg and L. Soete (eds.), Technical Change and Economic Theory, London: Pinter.

BRESCHI, S., F. MALERBA and L. ORSENIGO (2000), "Technological Regimes and Schumpeterian Patterns of Innovation", Economic Journal, Vol. 110, pp. 388-410.

CAHUC, P., and Ph. MICHEL (1996), "Minimum Wages, Unemployment and Growth", European Economic Review, Vol. 40, pp. 1463-1482

CAPPELLI, P. (2000), "Examining the Incidence of Downsizing and Its Effect on Establishment Performance", in D. Neumark (ed.), On the Job, New York: Russell Sage Foundation. 
CASPER, S., and H. GLIMSTEDT (2001), "Economic Organization, Innovation Systems, and the Internet", Oxford Review of Economic Policy, Vol. 17, pp. 265281.

CASPER, S., M. LEHRER and D. SOSKICE (1999), "Can High-Technology Industries Prosper in Germany? Institutional Frameworks and the Evolution of the German Software and Biotechnology Industries", Industry and Innovation, Vol. 6, pp. 5-24.

CHANG, C., and Y.WANG (1996), "Human Capital Investment under Asymmetric Information: The Pigouvian Conjecture Revisited", Journal of Labor Economics, Vol. 14, pp. 505-519.

CHATTERJEE, S., and A. HADI (1988) Sensitivity Analysis in Linear Regression, New York: Wiley.

COHEN, W., and D. LEVINTHAL (1989), "Innovation and Learning: The Two Faces of R\&D”, Economic Journal, Vol. 99, pp. 569-596.

DASGUPTA, P. and J. STIGLITZ (1980), "Industrial Structure and the Nature of Innovative Activity", Economic Journal, Vol. 90, pp. 226-293.

DAVIS, S. J. (1992), "Cross-Country Patterns of Change in Relative Wages", NBER Macroeconomic Annual, Vol. 7, pp. 239-292.

DOSI, G. (1988), "Sources, Procedures, and Microeconomic Effects of Innovation", Journal of Economic Literature, Vol. 26, pp. 1120-1171.

DOSI, G., and B. CORIAT (1998), "Learning How to Govern and Learning How to Solve Problems: On the Co-Evolution of Competences, Conflicts and Organizational Routines", in A. Chandler, P. Hagström and Ö. Sölvell (eds.), The Dynamic Firm: The Role of Technology, Strategy, Organization, and Regions, Oxford: Oxford University Press.

DUSO, T., and L.H. RÖLLER (2001), "Towards a Political Economy of Industrial Organization: Empirical Regularities from Deregulation”, WZB Discussion Paper, FS IV 01-03.

EICHENGREEN, B. and T. IVERSEN (1999), "Institutions and Economic Performance: Evidence from the Labour Market", Oxford Review of Economic Policy, Vol. 15, pp. 121-138.

ELMESKOV, J., J. MARTIN and S. SCARPETTA (1998), "Key Lessons for Labour Market Reforms: Evidence from OECD Countries' Experiences", Swedish Economic Policy Review, Vol. 5, pp. 205-252.

FLANAGAN, R. (1999), "Macroeconomic Performance and Collective Bargaining: An International Perspective", Journal of Economic Literature, Vol. 37, pp. 1150-75.

GEROSKI, P.A. (1990), "Innovation, Technological Opportunity, and Market Structure”, Oxford Economic Papers, Vol.. 42, pp. 586-602.

GINARTE, J., and W. PARK (1997), "Determinants of Patent Rights: A Cross-national Study", Research Policy, Vol. 26, pp. 283-301.

GOTTSCHALK, P., and T. SMEEDING (1997), "Cross National Comparisons of Earnings and Income Inequality", Journal of Economic Literature, Vol. 35, pp. 633-687.

GRILICHES, Z. (1990), "Patent Statistics as Economic Indicators: A Survey", Journal of Economic Literature, Vol. 28, pp. 1661-1797. 
HATZICHRONOGLOU, T. (1997), "Revision of the High-technology Sector and Product Classification", STI Working Paper No. 1997/2, OECD.

KAHN, L. (1998), "Collective Bargaining and the Inter-industry Wage Structure: International Evidence", Economica, Vol. 65, pp. 507-534.

KATZ, E., and A. ZIDERMAN (1990), "Investment in General Training: The Role of Information and Labor Mobility", Economic Journal, Vol. 100, pp. 1147-1158.

KITSCHELT, H. (1991), "Industrial Governance Structures, Innovation Strategies, and the Case of Japan: Sectoral or Cross-national Comparative Analysis?", International Organization, Vol. 45, pp. 453-493.

KUGLER, A., and G. SAINT-PAUL (2000), "Hiring and Firing Costs, Adverse Selection and Long-term Unemployment", IZA Discussion Paper, No. 134.

LYNCH, L. (1994) (ed.), Training and the Private Sector: International Comparisons, Chicago: University of Chicago Press for the NBER.

MALCOMSON, J. M. (1997), "Contracts, Hold-Up, and Labor Markets", Journal of Economic Literature, Vol. 35, pp. 1916-1957.

MALERBA, F. (2001), "Technological Regimes and Sectoral Systems of Innovation in Europe", paper presented at the conference on "The sources of technological change", Saint Gobain Centre for Economic Studies, Paris, June 2001.

MALERBA, F., and L. ORSENIGO (1995), "Schumpeterian Patterns of Innovation", Cambridge Journal of Economics, Vol. 19, pp. 47-65.

MALERBA, F., and L. ORSENIGO (1997), "Technological Regimes and Sectoral Patterns of Innovative Activities", Industrial and Corporate Change, Vol. 6, pp. 83-117.

MALERBA, F., and L. ORSENIGO (2000), "Knowledge, Innovative Activities and Industrial Evolution", Industrial and Corporate Change, Vol. 9, pp. 289-314.

MARCH, J. and H. SIMON (1958), Organizations, New York: Wiley.

MARSILI, O. (2001), The Anatomy and Evolution of Industries, Cheltenham: Elgar.

McCUE, K. (1996), "Promotions and Wage Growth", Journal of Labor Economics, Vol. 14, pp. 175-209.

NELSON, R. and S. WINTER (1982), An Evolutionary Theory of Economic Change, Cambridge, Mass.: The Belknap Press of Harvard University Press.

NICOLETTI, G., S. SCARPETTA and O. BOYLAUD (1999), "Summary Indicators of Product Market Regulation with an Extension to Employment Protection Legislation”, OECD Economics Department Working Papers, $\mathrm{N}^{\mathrm{o}} 226$.

SCARPETTA, S. (1996), "Assessing the Role of Labour Market Policies and Institutional Settings on Unemployment: A Cross-Country Study", OECD Economic Studies, Vol. 26, pp. 43-98.

SOSKICE, D. (1997), "German Technology Policy, Innovation, and National Institutional Frameworks", Industry and Innovation, Vol. 4, pp. 75-96.

STEVENS, M. (1994), "A Theoretical Model of On-the-job Training with Imperfect Competition”, Oxford Economic Papers, Vol. 46, pp. 537-562.

SUTTON, J. (1998), Technology and Market Structure, Cambridge, Mass.: The MIT Press. 
TEMPLE, J. (1999), “A Positive Effect of Human Capital on Growth”, Economics Letters, Vol. 65, pp. 131-134.

TEMPLE, J. (2001), “Generalizations That Aren't? Evidence on Education and Growth", European Economic Review, Vol. 45, pp. 905-918.

TEULINGS, C., and J. HARTOG (1998), Corporatism or Competition? Labour Contracts, Institutions and Wage Structures in International Comparison, Cambridge: Cambridge University Press.

ZIMMERMANN, K. (1998), "German Job Mobility and Wages", in I. Ohashi and T. Tachibanaki (eds.), Internal Labour Markets, Incentives and Employment, London: MacMillan. 